\title{
How plausible is the use of dietary $n-3$ PUFA in the adjuvant therapy of cancer?
}

\author{
Simona Serini ${ }^{1 *}$, Renata Ottes Vasconcelos ${ }^{2}$, Elena Fasano ${ }^{1}$ and Gabriella Calviello ${ }^{1 *}$ \\ ${ }^{1}$ Institute of General Pathology, Università Cattolica del S. Cuore, L.go F. Vito, 1-00168 Rome, Italy \\ ${ }^{2}$ Institute of Biological Sciences, Federal University of Rio Grande, Avenida Itàlia, km 8, Campus Carreiros, Rio Grande/RS. \\ 962011-900, Brazil
}

\section{Abstract}

Considerable debate exists regarding the potential antineoplastic effect of dietary long-chain $n$ - 3 PUFA contained in fatty fishes. Since the majority of published data has proven that their intake does not induce toxic or carcinogenic effects in humans, their possible preventive use against cancer has been suggested. On the other hand, it is unlikely that they could be effective in cancer patients as a single therapy. Nevertheless, a considerable effort has been put forth in recent years to evaluate the hypothesis that $n-3$ PUFA might improve the antineoplastic efficiency of currently used anticancer agents. The rationale for this therapeutic combinatory strategy is trying to increase cancer sensitivity to conventional therapies. This could allow the use of lower drug/radiation doses and, thereby, a reduction in the detrimental health effects associated with these treatments. We will here critically examine the studies that have investigated this possibility, by focusing particularly on the biological and molecular mechanisms underlying the antineoplastic effect of these combined treatments. A possible use of $n-3$ PUFA in combination with the innovative single-targeted anti-cancer therapies, that often are not completely devoid of dangerous side-effects, is also suggested.

Key words: Antineoplastic drugs: Combinations: Human trials: Preclinical studies: $\boldsymbol{n}$-3 PUFA

\section{Introduction}

The past few years have seen a renewed interest in dietary long-chain $n-3$ PUFA (LC- $n$-3-PUFA) and their possible beneficial effects in numerous chronic diseases ${ }^{(1,2)}$

$n$-3 PUFA are hydrocarbon chains containing two or more double bonds. They belong to the $n-6$ or $n-3$ class depending on the position of the first double bond starting from the terminal methyl group. The parent fatty acids (FA) of the two $n-6$ and $n-3$ PUFA families are linoleic acid (LA; $18: 2 n-6$ ) and $\alpha$-linolenic acid (ALA; 18:3n-3), both considered dietary essential FA, since they cannot be endogenously synthesised by mammals. High amounts of LA are present in vegetable oils, seeds and nuts, whereas ALA is especially contained in leafy vegetables, seeds, walnuts, soyabeans, flaxseed and seed oils. Once entered into our cells, both FA are metabolised by a series of elongation and desaturation reactions to LC-PUFA. LA is converted to arachidonic acid (AA; $20: 4 n-6)$, whereas ALA to EPA (20:5n-3), and finally to DHA (22: 6n-3). However, the endogenous production of EPA and DHA from ALA is not very efficient, especially at some ages and conditions; thus, the consumption of fish represents an alternative and more efficient route to enrich our tissues with these $\mathrm{FA}^{(3)}$
The antineoplastic effects of $n-3$ PUFA have been studied for over 20 years in our laboratory by performing human trials ${ }^{(4-6)}$, or preclinical studies on experimental animals ${ }^{(7-10)}$ and cultured cells $^{(11-16)}$. All the results obtained have concurred to demonstrate the anti-neoplastic role of EPA and DHA. In particular, two clinical trials performed in the early 1990s showed that dietary supplementation with both EPA and DHA was able to normalise the atypical cell proliferation pattern present in the colonic mucosa of subjects at high risk for colon cancer ${ }^{(4,5)}$. We also demonstrated that EPA and DHA treatments delayed the development and reduced the growth of murine and human cancer cells transplanted in syngeneic animals ${ }^{(7-10)}$ or in nude mice ${ }^{(11)}$.

So far, multiple biological mechanisms have been suggested to explain the inhibitory effects of LC- $n-3$ PUFA on cancer cell growth, and, particularly, their ability to induce apoptosis in cancer cells ${ }^{(7,11,12,14-21)}$. Several molecular pathways are thought to be involved in their growth-inhibitory effect (Fig. 1). For instance, it has been proven that they induce deep alterations in the composition and function of lipid membrane microdomains (rafts and caveolae; mechanism A in Fig. 1). It has been suggested that such perturbations may alter the function of resident proteins (receptors, enzymes, transporters,

Abbreviations: 5-FU, 5-fluorouracil; AA, arachidonic acid; ALA, $\alpha$-linolenic acid; COX, cyclo-oxygenase; FA, fatty acid; FO, fish oil; i.v., intravenous; LC- $n$-3PUFA, long-chain $n-3$ PUFA; MDR, multidrug resistance; NSCLC, non-small cell lung cancer; PARP, poly(ADP-ribose) polymerase; ROS, reactive oxygen species; TRAIL, TNF-related apoptosis-inducing ligand.

*Corresponding authors: S. Serini, email simona.serini@rm.unicatt.it; G. Calviello, email g.calviello@rm.unicatt.it 


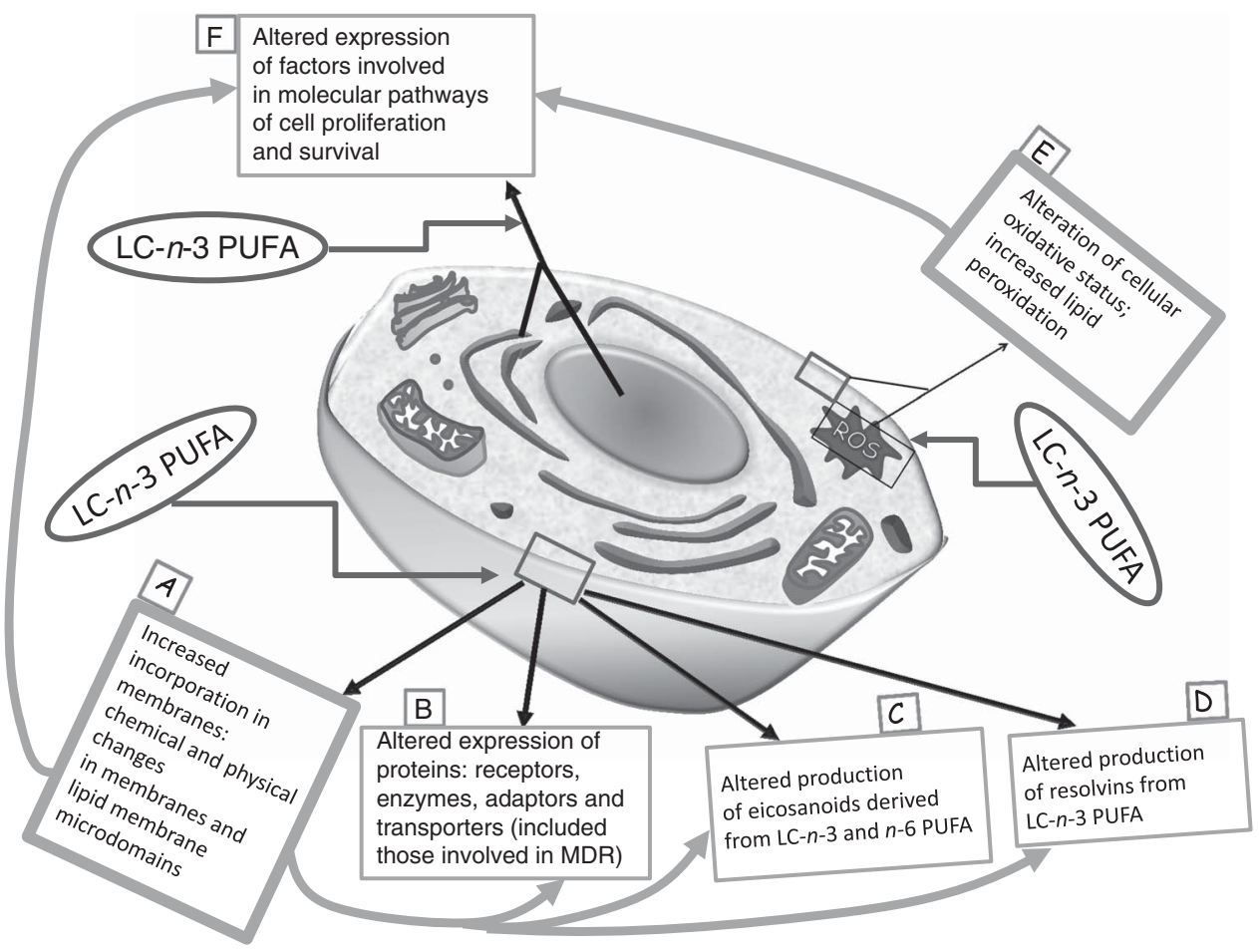

Fig. 1. Main mechanisms proposed to explain the inhibitory effect of long-chain (LC)- $n$-3 PUFA on cancer cell growth. It is possible to hypothesise that the activation of the molecular mechanisms $\mathrm{A}$ and $\mathrm{E}$ (in bold boxes, 'unifying mechanisms') may be more directly related to the treatment with $n-3$ PUFA. As a consequence, other mechanisms (in thin boxes: B, C, D and F) may be induced. MDR, multidrug resistance; ROS, reactive oxygen species.

adaptors; mechanism B in Fig. 1), and, in turn, the intracellular molecular responses associated with them ${ }^{(22)}$. Moreover, it is well documented that they are able to deeply alter the cellular metabolism of eicosanoids (mechanism $C$ in Fig. 1), bioactive molecules originating from EPA and AA and involved in cell signalling. These FA are cleaved from cell membrane phospholipids by phospholipase $\mathrm{A}_{2}$, and further metabolised by the enzymes cyclo-oxygenases (COX) and lipo-oxygenases, which convert them into PG, leukotrienes and thromboxanes. EPA competes with AA for these enzymes, but whereas the eicosanoids derived from AA have powerful inflammatory and proliferative activity, those derived from EPA exert scarce pro-inflammatory activity and, instead, have anti-proliferative effects $^{(23)}$. Recently, new enzymically derived products of EPA and DHA (resolvins and protectins) were identified (mechanism $\mathrm{D}$ in Fig. 1) ${ }^{(24)}$. They show powerful activity in vitro and in vivo at nanomolar or picomolar concentrations in the resolution phase of inflammation or by acting as neuroprotective agents ${ }^{(25-27)}$. Since the pathogenic role of inflammation in the development of many kinds of tumours ${ }^{(28)}$ was well established, the antineoplastic activity of $n-3$ PUFA has also been related to the action of these bioactive molecules. Furthermore, although there is still much debate as to whether $n-3$ PUFA may function in our tissues as pro-oxidants or antioxidants ${ }^{(29)}$, most of the findings concur to demonstrate that $n$ - 3 PUFA are able to sensitise cells to reactive oxygen species (ROS) through their high peroxidability, due to the presence in their hydrocarbon chain of multiple double bonds (mechanism E in Fig. 1) ${ }^{(30)}$. This mechanism has been invoked by a number of studies correlating the cytotoxic action of $n-3$ PUFA in cancer cells in vitro with their pro-oxidant potential ${ }^{(31-33)}$, and the formation of cytotoxic metabolic intermediates ${ }^{(34)}$. Many reports have also demonstrated the ability of $n-3$ PUFA to modulate the expression of several proteins and transcription factors involved in the molecular pathways associated with cell proliferation and survival (mechanism F in Fig. 1) ${ }^{(35)}$. The multiplicity of mechanisms activated by these FA may be disorienting. However, it is possible to hypothesise ${ }^{(35)}$ that the activation of some of them (such as mechanisms $\mathrm{A}$ and $\mathrm{E}$ in Fig. 1) may be more directly related to $n-3$ PUFA. These mechanisms could be considered as starting points for the activation of further LC- $n-3$ PUFAdependent secondary mechanisms (such as mechanisms B, C, D and $\mathrm{F}$ in Fig. 1).

The idea of a possible preventive usage of LC-PUFA against cancer has become quite acceptable, since within an established range of doses $(0.5-2 \mathrm{~g} / \mathrm{d})$, most of the published data have proven that their intake cannot be considered dangerous, or induce toxic or carcinogenic effects ${ }^{(36)}$. Since they are usual components of our diet, a preventive use could be simply realised by increasing the consumption of $n$ - 3 PUFA-rich foods or by supplementing them in capsules containing marine oils or EPA and/or DHA in a purified form. On the other hand, it is unlikely that dietary supplementation alone could be an effective therapy for cancer patients. Instead, because of their pleiotropic effects, and their ability to modulate many biological processes and molecular pathways in the cells, an interesting hypothesis has been considered. It suggests that $n$ - 3 PUFA could be administered in combination with the currently used anticancer agents, with the main aim to enhance the efficacy of these therapeutic treatments, as well as to reduce their 
side effects. Several years ago, we reviewed all the studies that had evaluated this new combined therapeutic strategy up to that point ${ }^{(37)}$. However, additional and interesting papers have been published on this subject meanwhile. Moreover, we are recently witnessing an upsurge of interest in n-3 PUFA as anti-inflammatory and anti-neoplastic agents. Thus, in the present review we will update the analysis of the existing data regarding the beneficial effects exerted by $n-3$ PUFA in combination with anti-neoplastic drugs and radiation.

\section{Methodology \\ Literature search}

A systematic literature search of the PubMed database was conducted in the period from July 2014 to July 2015 to identify published peer-reviewed original research articles regarding in vitro studies, and in vivo animal and human interventional studies on $n$-3 PUFA combined with conventional (chemotherapy or radiotherapy) cancer therapies. The main search terms used for the search of titles and abstracts were: 'omega-3 PUFA' or ' $n-3$ PUFA' or 'docosahexaenoic acid' or 'eicosapentaenoic acid' or 'fish oil'; and 'animal studies', or 'human studies', or 'in vitro studies', or 'in vivo studies'; and 'chemotherapy' or 'radiotherapy' or 'antineoplastic drug' and 'cancer' or 'tumor'; and 'combination' or 'combined treatment'. We mostly identified full-text articles written in English. The papers were chosen without restriction of time. Of course, whatever the criteria used to choose papers to be analysed, it is useful to be reminded that, as recently emphasised by Song et al. ${ }^{(38)}$, there still remains the tendency of researchers and journal editors to prefer the outcomes showing significant findings. This, however, represents a bias in all fields of published literature.

\section{Presentation of data}

The in vitro studies were first considered, followed by the preclinical animal studies and the human clinical interventional trials. The results and the molecular mechanisms invoked were critically analysed. The results were also summarised in several comprehensive tables reporting the information for each therapeutic combination studied, the concentrations/dose of both anticancer drugs/radiation and $n-3$ PUFA/fish oils (FO), the cellular/animal models used or the types of clinical trials performed, and the anticancer as well as the biological and molecular effects obtained.

\section{In vitro studies}

A broad range of experimental in vitro studies, mainly performed on colon and breast cancer cell lines, as well as on leukaemia cells, have demonstrated an enhanced efficacy of treatments with conventional antineoplastic agents (either drugs or radiation) when they were administered in combination with n-3 PUFA. Just a few experimental studies were also performed by using cancer cells originating from other tissues. We will analyse the studies in four separate paragraphs on the basis of the cancer cells used (colon cancer cells, breast cancer cells, leukaemia/lymphoma and myeloma cells, and other kinds of cancer cells). This paragraph division is related to the fact that the antineoplastic treatments administered in combination were usually specific for each kind of cancer cells, that is, those generally employed against the human cancers derived from those cells.

\section{Colon cancer cells}

All of the results obtained by adding LC- $n-3$ PUFA to colon cancer cells treated in vitro with anti-neoplastic agents have concurred to demonstrate a remarkable enhancement in the ability of cells to undergo apoptosis (Table 1 and Table 2). In most of the papers analysed, the possible molecular changes underlying this effect were also investigated. Several years ago, we demonstrated that DHA was able to enhance the efficacy of 5-fluorouracil (5-FU), one of the most widely used drugs in the therapy of this type of cancer. DHA induced a synergistic growth-inhibitory and pro-apoptotic effect in four different types of human colon cancer cells, and this effect was independent on cell p53 status ${ }^{(12)}$. This result is interesting, since it is known that therapy with 5 -FU is less effective in patients bearing p53-mutant colon cancers, and also because the anti-tumour effect was observed with concentrations of 5-FU lower than those commonly found in the serum of patients treated with 5 -FU (in the range $0 \cdot 1-1 \mu \mathrm{M})^{(12)}$. This finding suggested that $n$ - 3 PUFA in vivo could increase the therapeutic potential of low doses of 5-FU, and, thus, avoid the undesired side effects associated with high 5-FU doses. More recently, Granci et al. ${ }^{(39)}$ confirmed these results, showing that a FO emulsion (corresponding to about $45 \mu \mathrm{m}-\mathrm{EPA}+\mathrm{DHA}$ ) enhanced the pro-apoptotic effect of $1 \mu \mathrm{m}-5-\mathrm{FU}$ in HT-29 cells, whereas a soyabean oil emulsion was ineffective. The authors ascribed this effect to the ability of the FO emulsion to activate the Bax-dependent apoptotic pathway. Also Jordan \& Stein ${ }^{(40)}$ investigated the effect of a combination of $5-\mathrm{FU}$ and a FO-based lipid emulsion rich in $n-3$ FA in Caco- 2 colon cancer cells. In agreement with our results, they found that the combination FO emulsion/5-FU additively inhibited cell growth, both decreasing cell cycle progression and inducing apoptosis.

The same $n$-3 PUFA/5-FU combination was investigated recently in colon cancer stem-like cells (CSLC). It was observed that EPA increases the sensitivity of the CD $133^{+}$CSLC to $5-\mathrm{FU}^{(41)}$. This may represent a highly innovative frontier in the field of new possible therapeutic strategies using antineoplastic agents $/ n-3$ combinations. A growing body of evidence supports the hypothesis that human cancer is a stem cell disease, and that only the CSLC fraction possesses cancer-initiating potential, as well as the ability to sustain a tumour ${ }^{(42,43)}$. Moreover, it has been shown that these cells have a role in the acquisition of chemotherapy resistance and tumour relapse. Interestingly, it has been observed that EPA is able to down-regulate the expression of $\mathrm{CD} 133^{(41)}$, a marker used to isolate populations of colon cancer cells that retain stem cell properties from both established cell lines and primary cell cultures. On the contrary, EPA increased the expression of differentiation markers in colonic epithelium, such as cytokeratin 20 and mucin $2^{(41)}$. Moreover, in a recent study performed in chemoresistant colon 
Table 1. Colon cancer cells in vitro: effects of $n-3$ PUFA in combination with conventional antineoplastic agents

\begin{tabular}{|c|c|c|c|c|c|}
\hline Cell type & Antineoplastic drug & $n-3$ PUFA treatment & Anticancer effect(s) & $\begin{array}{l}\text { Biochemical and } \\
\text { molecular effects }\end{array}$ & Reference \\
\hline $\begin{array}{l}\text { LS-174, Colo } 320 \\
\text { HSR, Colo } 205 \text {, } \\
\text { HT-29 }\end{array}$ & $5-F U(0.1-7.5 \mu \mathrm{m})$ & DHA (10-50 $\mu \mathrm{m})$ & $\begin{array}{l}\uparrow \text { Cell growth inhibition } \\
\uparrow \text { Apoptosis induction } \\
\downarrow \text { Cell cycle progression }\end{array}$ & $\begin{array}{l}\downarrow \mathrm{Bcl}-2, \mathrm{Bcl}-\mathrm{xL} \text { expression } \\
\uparrow \mathrm{c} \text {-myc expression }\end{array}$ & 12 \\
\hline HT-29 & 5-FU $(1 \mu \mathrm{m})$ & $\begin{array}{l}\text { FO-based lipid emulsion } \\
(20.6 \mathrm{~g} / \mathrm{l} \mathrm{EPA} \text { and } 19 \mathrm{~g} / \mathrm{I} \mathrm{DH}) \\
\text { to a final concentration of } \\
24 \mu \mathrm{M}-\mathrm{EPA} \text { and } 20.5 \mu \mathrm{M}-\mathrm{DHA}\end{array}$ & $\uparrow$ Apoptosis induction & $\begin{array}{l}\downarrow \Delta \psi \mathrm{m} \\
\uparrow \text { Caspase-9 activation }\end{array}$ & 39 \\
\hline Caco-2 & $5-\mathrm{FU}(0.25-1 \mu \mathrm{m})$ & $\begin{array}{l}\text { FO-based lipid emulsion } \\
\text { ( } 21 \mathrm{~g} / \mathrm{l} \text { EPA and } 17 \mathrm{~g} / \mathrm{l} \mathrm{DHA}) \\
\text { to a final concentration of } \\
10-50 \mu \mathrm{M}-\mathrm{EPA} \text { and } \\
7.5-37.5 \mu \mathrm{M}-\mathrm{DHA}\end{array}$ & $\begin{array}{l}\uparrow \text { Cell growth inhibition } \\
\uparrow \text { Apoptosis induction }\end{array}$ & Not investigated & 40 \\
\hline COLO 320 DM & $\begin{array}{l}\text { 5-FU }(0.05-2 \mathrm{~mm}) \\
\text { Oxaliplatin }(0.005- \\
0.1 \mathrm{~mm})\end{array}$ & EPA $(25 \mu \mathrm{m})$ & $\downarrow$ Cell viability & $\begin{array}{l}\uparrow \text { CK20 and MUC2 } \\
\text { expression } \\
\downarrow \text { CD133 expression }\end{array}$ & 41 \\
\hline $\begin{array}{l}\text { Chemoresistant } \\
\text { HT-29 and } \\
\text { HCT-116 }\end{array}$ & $\begin{array}{l}\text { 5-FU }(50 \mathrm{mM}) \text {, oxaliplatin } \\
\quad(1.25 \mathrm{~mm})\end{array}$ & EPA $(10-20 \mu \mathrm{m})$ & $\begin{array}{l}\uparrow \text { Inhibition of cell growth and } \\
\text { colonosphere formation } \\
\uparrow \text { Sphere disintegration } \\
\downarrow \text { CSC/CSLC population }\end{array}$ & $\begin{array}{l}\uparrow \text { Cleavage of PARP } \\
\uparrow \text { pPTEN expression } \\
\downarrow \text { pAKT expression } \\
\downarrow \beta \text {-Catenin expression }\end{array}$ & 44 \\
\hline Caco-2 & p-XSC (2.5 $\mu \mathrm{m})$ & DHA $(2.5 \mu \mathrm{M})$ & $\begin{array}{l}\uparrow \text { Cell growth inhibition } \\
\uparrow \text { Apoptosis induction }\end{array}$ & $\begin{array}{l}\downarrow \beta \text {-Catenin, COX-2, iNOS, } \\
\text { cyclin D1 expression }\end{array}$ & 46 \\
\hline $\mathrm{HT}-29$ & TRAIL $(200 \mathrm{ng} / \mathrm{ml})$ & $\mathrm{DHA}(100 \mu \mathrm{m})$ & $\begin{array}{l}\downarrow \text { Cell viability } \\
\uparrow \text { Apoptosis induction }\end{array}$ & $\begin{array}{l}\uparrow \text { ROS production } \\
\uparrow \text { Pro-caspase } 3 \text { and } 8 \\
\quad \text { expression } \\
\downarrow \Delta \psi \mathrm{m} \\
\downarrow \text { Bid, PARP expression }\end{array}$ & 47 \\
\hline
\end{tabular}

5-FU, 5-fluorouracil; FO, fish oil; $\triangle \psi$ m, mitochondrial membrane potential; CK20, cytokeratin 20; MUC2, mucin 2; CSC, cancer stem cells; CSLC, cancer stem-like cells; PARP, poly(ADP-ribose) polymerase; AKT, protein kinase B; PTEN, phosphatase and tensin homolog; p-XSC, 1,4-phenylenebis(methylene)selenocyanate; COX-2, cyclo-oxygenase-2; iNOS, inducible NO synthase; TRAIL, TNF-related apoptosis-inducing ligand; ROS, reactive oxygen species

cancer cells highly enriched in CSC, it was shown that EPA improved the ability of 5-FU + oxaliplatin (FuOx) not only in inhibiting colon cancer cell growth and colonosphere formation, but also in reducing CSC population. Also in this case the suppression of cancer cell growth was the result of increased apoptosis, as evidenced by poly(ADP-ribose) polymerase (PARP) cleavage ${ }^{(44)}$.

Moreover, on the basis of previous epidemiological and preclinical studies showing that diets rich in Se had the potential to reduce the incidence of colon cancer ${ }^{(45)}$, Narayanan et al. ${ }^{(46)}$ evaluated the effect of a combination of DHA with 1,4phenylene bis(methylene) selenocyanate, a synthetic organoselenium compound less toxic and more effective than inorganic Se. Interestingly, it was observed that the combined treatment efficiently inhibited colon cancer cell growth by enhancing apoptosis ${ }^{(46)}$. They suggested that the effect could be related to the down-regulation of several genes involved in colon cancer cell growth (i.e. COX-2, inducible NO synthase, cyclin $\mathrm{D}_{1}, \beta$-catenin and NF- $\mathrm{B}$-p65).

Of great interest are also the results showing that DHA is able to sensitise human colon adenocarcinoma HT-29 cells to the apoptosis induced by TNF-related apoptosis-inducing ligand (TRAIL) ${ }^{(47,48)}$. This is a member of the TNF family and a very promising anti-cancer agent ${ }^{(49)}$, since it possesses the unique property to induce cancer cell death while sparing most normal cells ${ }^{(49)}$. However, its clinical application has been so far hampered due to the resistance that some cancer cells show to TRAIL-induced apoptosis ${ }^{(50)}$. For this reason, possible combinations of TRAIL with apoptosis inducers able to synergise with it and, thus, sensitise apoptosis-resistant cancer cells have been intensively studied over the last 10 years ${ }^{(51)}$. Based on the results obtained, the combinatory strategy is considered very promising, even though to be still verified in clinical settings. Particularly, Skender et al. ${ }^{(48)}$ recently showed that DHA sensitised cancer cells to the pro-apoptotic effect of TRAIL thanks to its ability to activate Bax and Bak, whose down-regulation had been associated with resistance to TRAIL ${ }^{(52,53)}$. Moreover, DHA acted also by activating the endoplasmic reticulum stress response and up-regulating CCAAT-enhancer-binding protein homologous protein (CHOP). This is one of the pathways considered crucial to be targeted in a combinatory treatment with TRAIL ${ }^{(51)}$.

The exposure to photodynamic therapy or radiation induces apoptosis in colon cancer cells, and the combined treatment with DHA, EPA or conjugated EPA was shown to enhance $\mathrm{it}^{(54-57)}$. The mechanism proposed to explain the pro-apoptotic effect of these combinations was increased oxidative stress and lipid peroxidation, which may also activate the inflammatory response ${ }^{(54-57)}$, as well as the increased DNA damage due to decreased expression of DNA polymerases ${ }^{(55)}$. 
Table 2. Colon cancer cells in vitro: effects of $n$-3 PUFA in combination with conventional antineoplastic agents

\begin{tabular}{|c|c|c|c|c|c|}
\hline Cell type & Antineoplastic drug & $n$-3 PUFA treatment & Anticancer effect(s) & Biochemical and molecular effects & Reference \\
\hline $\begin{array}{l}\text { SW620, SW480, } \\
\text { DLD-1 }\end{array}$ & TRAIL $(2 \cdot 5-25 \mathrm{ng} / \mathrm{ml})$ & $\mathrm{DHA}(50 \mu \mathrm{m})$ & $\begin{array}{l}\downarrow \text { Cell viability } \\
\uparrow \text { Apoptosis induction }\end{array}$ & $\begin{array}{l}\uparrow \text { Cleavage of caspase-8, }-9 \\
\quad \text { and }-3 \text { and Bid } \\
\uparrow \text { Cytochrome c release } \\
\uparrow \text { CHOP expression } \\
\uparrow \text { Bax and Bak activation } \\
\downarrow \Delta 4 \mathrm{~m} \\
\downarrow \text { cIAP1 and XIAP level } \\
\downarrow \text { PERK expression }\end{array}$ & 48 \\
\hline HT-29 & $\begin{array}{l}\text { Hypericin }(150 \mathrm{~nm}) \text {; PDT } \\
\left(3.15 \mathrm{~mW} / \mathrm{cm}^{2}\right)\end{array}$ & DHA $(150 \mu \mathrm{M})$ & $\begin{array}{l}\uparrow \text { Cytotoxicity } \\
\uparrow \text { Apoptosis induction }\end{array}$ & $\begin{array}{l}\uparrow \text { ROS and RNS production } \\
\uparrow \text { Lipoperoxidation }\end{array}$ & 54 \\
\hline HCT116 & Radiation (7.8 Gy/min) & cEPA $(100 \mu \mathrm{m})$ & $\begin{array}{l}\uparrow \text { Radiosensitivity } \\
\uparrow \text { Apoptosis induction } \\
\downarrow \text { Cell survival }\end{array}$ & $\begin{array}{l}\downarrow \text { Pols } \beta, \delta \text { and } \varepsilon \text { expression } \\
\uparrow \text { DNA damage }\end{array}$ & 55 \\
\hline HT-29, LS174T & Radiation (0-4 Gy) & EPA, DHA (20 or $50 \mu \mathrm{m})$ & $\uparrow$ Cell death, apoptosis & $\begin{array}{l}\uparrow \text { Lipid peroxidation, Hsp70 expression } \\
\uparrow \text { NF-kB p65, COX-2, Bcl-2 expression }\end{array}$ & 56 \\
\hline HT-29 & Radiation (4-8Gy) & EPA $(30 \mu \mathrm{m})$ & $\uparrow$ Radiosensitivity & $\uparrow$ Lipid peroxidation & 57 \\
\hline $\begin{array}{l}\text { HCT116, LoVo, } \\
\text { SNU-C4 }\end{array}$ & $\begin{array}{l}\text { Sulindac sulfide } \\
\quad(100-125 \mu \mathrm{M})\end{array}$ & DHA $(15-20 \mu \mathrm{m})$ & $\uparrow$ Apoptosis & $\begin{array}{l}\uparrow \text { PARP cleavage } \\
\uparrow \text { Caspase- } 8 \text { activation }\end{array}$ & 58 \\
\hline Caco-2 & Paclitaxel $(2 \cdot 5-5 \mathrm{~nm})$ & EPA, DHA $(50-100 \mu \mathrm{m})$ & $\begin{array}{l}\uparrow \text { Cytotoxicity } \\
\uparrow \text { Apoptosis induction }\end{array}$ & $\begin{array}{l}\downarrow \text { P-gp expression } \\
\uparrow \mathrm{CAR} \text { and } \mathrm{RXR} \text { receptor mRNA }\end{array}$ & 60 \\
\hline HT29-dx & $\begin{array}{l}\text { Doxorubicin }(5 \mu \mathrm{M}) \\
\text { Irinotecan }(1 \mu \mathrm{M})\end{array}$ & EPA, DHA $(50 \mu \mathrm{M})$ & $\uparrow$ Cell growth inhibition & $\begin{array}{l}\uparrow \text { Trc8 E3 ligase activation } \\
\uparrow \text { HMGCoAR ubiquitination } \\
\downarrow \text { Cholesterol synthesis } \\
\downarrow \text { P-gp and MRP1 expression }\end{array}$ & 66 \\
\hline
\end{tabular}

TRAIL, TNF-related apoptosis-inducing ligand; CHOP, C/EBP homology protein; $\Delta \psi \mathrm{m}$, mitochondrial membrane potential; clAP, cellular inhibitor of apoptosis protein; XIAP, $\mathrm{X}$-linked inhibitor of apoptosis protein; PERK, protein kinase RNA-like endoplasmic reticulum kinase; PDT, photodynamic therapy; ROS, reactive oxygen species; RNS, reactive $\mathrm{N}$ species; cEPA, conjugated EPA; Pols, DNA polymerases; COX-2, cyclo-oxygenase-2; PARP, poly(ADP-ribose) polymerase; P-gp, P-glycoprotein; CAR, constitutive androstane receptor; RXR, retinoid X receptor; HMGCoAR, 3-hydroxy-3-methylglutaryl-coenzyme A reductase; MRP1, multidrug resistant related protein 1.

In agreement, it was recently shown that treatment of different colon cancer cells with DHA was able to enhance sulindac-sulfide-induced apoptosis in vitro through an enhanced cleavage of PARP and caspase- 8 activation ${ }^{(58)}$. This finding is interesting, since sulindac analogues are compounds belonging to the group of non-steroidal anti-inflammatory drugs, and are well known for being extremely efficacious in reducing colon cancer risk ${ }^{(59)}$. This finding was confirmed in the same paper also in vivo, by showing that the simultaneous intraperitoneal treatment with sulindac and DHA was able to suppress the growth of tumours derived from colorectal cancer cells transplanted in nude mice more efficiently than the treatment of each single compound administered alone.

Finally, the treatment of Caco-2 colon adenocarcinoma with both $\mathrm{EPA}+$ DHA was recently observed ${ }^{(60)}$ to significantly enhance the pro-apoptotic effect of paclitaxel, a well-known antineoplastic agent used in the treatment of different types of cancers. The authors found that both DHA and EPA were able to reduce the expression of the drug transporter protein P-glycoprotein (P-gp), involved in the development of multidrug resistance (MDR) during cancer progression. This findings is of interest, since the resistance of tumour cells to conventional anticancer drugs represents a problem for the success of cancer chemotherapy ${ }^{(61)}$. It is known that MDR can be caused in part by the expression of three drug transporter proteins: ABCB1/P-gp, ABCC1/multidrug resistance protein-1 (MRP1) and ABCG2/breast cancer resistance protein, belonging to the ATP-binding cassette (ABC) superfamily and possessing the function of ATP-dependent drug-efflux pumps ${ }^{(62)}$. Moreover, it has been shown that the activity of P-gp and MRP1 is increased by high amounts of cholesterol in the plasma membrane and detergent-resistant membranes ${ }^{(63-65)}$. In keeping, Gelsomino et al. ${ }^{(66)}$ recently reported that $n-3$ PUFA were able to sensitise MDR colon cancer cells to doxorubicin by a mechanism involving the down-regulation of endogenous cholesterol synthesis. These results demonstrate that MDR may be targeted by $n-3$ PUFA in colon cancer cells, and that the inhibition of MDR may represent one of the main pathways through which these FA may enhance the antineoplastic efficacy of some of the conventional chemotherapeutic drugs.

\section{Breast cancer cells}

In contrast to what is observed in colon cancer cells, the increased sensitivity of breast cancer cells to chemotherapeutic drugs administered in combination with LC- $n$-3 PUFA (Table 3 ) has been almost totally ascribed to the enhanced cytotoxic pro-oxidant effect of the drugs. Reasonably, this may be due to the use of drugs that themselves act mainly through a prooxidant mechanism. In two articles ${ }^{(67,68)}$ doxorubicin was used, and it was observed that DHA enhanced oxidative stressdependent cytotoxicity induced by this drug, and increased the 
Table 3. Breast cancer cells in vitro: effects of $n-3$ PUFA in combination with conventional antineoplastic drugs

\begin{tabular}{|c|c|c|c|c|c|}
\hline Cell type & Antineoplastic drug & $n$-3 PUFA treatment & $\begin{array}{l}\text { Anticancer } \\
\text { effect(s) }\end{array}$ & $\begin{array}{l}\text { Biochemical and } \\
\text { molecular effects }\end{array}$ & Reference \\
\hline MDA-MB-231 & Doxorubicin $(0.1 \mu \mathrm{m})$ & $\mathrm{DHA}(29 \mu \mathrm{m})$ & $\uparrow$ Cytotoxicity & $\uparrow$ Lipid peroxidation & 67 \\
\hline MDA-MB-231, MCF-7dox* & $\begin{array}{l}\text { Doxorubicin } \\
\qquad(0.1-100 \mu \mathrm{m})\end{array}$ & $\mathrm{DHA}(30 \mu \mathrm{m})$ & $\uparrow$ Cytotoxicity & $\uparrow$ Lipid peroxidation & 68 \\
\hline MDA-MB-231 & Doxorubicin (5 nм) & $\mathrm{DHA}(30 \mu \mathrm{m})$ & $\uparrow$ Cytotoxicity & $\begin{array}{l}\uparrow \text { ROS production } \\
\downarrow \text { GPx activity }\end{array}$ & 69 \\
\hline MDA-MB-231, SK-BR-3, BT-474 & $\begin{array}{l}\text { Paclitaxel, docetaxel } \\
\quad(0-25 \mathrm{~nm})\end{array}$ & DHA $(0-40 \mu \mathrm{g} / \mathrm{ml})$ & $\uparrow$ Cytotoxicity & $\downarrow$ Her-2/neu expression & 70 \\
\hline MDA-MB-231 & $\begin{array}{l}\text { Doxorubicin } \\
\qquad(0.22 \mu \mathrm{g} / \mathrm{ml})\end{array}$ & $\mathrm{DHA}(60 \mu \mathrm{M})$ & $\uparrow$ Apoptosis induction & $\begin{array}{l}\uparrow \text { CD95 surface expression } \\
\uparrow \text { Plasma membrane raft } \\
\text { content of CD95 } \\
\uparrow \text { FADD expression }\end{array}$ & 71 \\
\hline SK-BR-3 & $\mathrm{As}_{2} \mathrm{O}_{3}(1 \mu \mathrm{m})$ & EPA $(100 \mu \mathrm{M})$ & $\downarrow$ Cell viability & $\uparrow$ Lipid peroxidation & 73 \\
\hline MDA-MB-231 & & $\begin{array}{l}\text { DHA-propofol, } \\
\text { EPA-propofol } \\
\text { conjugates }(25 \mu \mathrm{M})\end{array}$ & $\begin{array}{l}\downarrow \text { Cell adhesion } \\
\downarrow \text { Cell migration } \\
\uparrow \text { Apoptosis induction }\end{array}$ & Not investigated & 74 \\
\hline MDA-MB-231 & & (LOV-DHA) conjugate $(1 \mu \mathrm{m})$ & $\uparrow$ Apoptosis induction & $\downarrow$ Cholesterol synthesis & 77 \\
\hline
\end{tabular}

MCF-7dox*, doxorubicin-resistant MCF-7 cells; ROS, reactive oxygen species; GPx, glutathione peroxidase; Her-2/neu, human epidermal growth factor receptor-2; FADD, Fas-associated death domain-containing protein; LOV, lovastatin.

production of lipid peroxidation products in breast cancer cells (MDA-MB-231 and MCF-7dox, a doxorubicin-resistant cell line, derived from the parental MCF-7 cells). These findings were further confirmed by the observation ${ }^{(69)}$ that the enhanced cytotoxicity induced by DHA in anthracycline-treated MDAMB-231 breast cancer cells was concomitant with a decreased activity and expression of glutathione peroxidase, an antioxidant enzyme playing a key role against hydrogen and lipid peroxides. It was also observed ${ }^{(70)}$ that DHA was able to synergistically enhance the taxane cytotoxicity in the highly metastatic MDA-MB-231 cells treated with paclitaxel or docetaxel. In this case, however, the pro-apoptotic effects of $n-3$ PUFA could be involved, since the main mechanism through which taxanes are believed to exert cytotoxicity and anti-tumour activity is microtubule stabilisation and induction of cell cycle arrest and apoptosis. According with all these findings, it has been reported that DHA is able to improve the growth-inhibitory effect of doxorubicin in oestrogen receptor-negative MDA-MB-231 cells, and that the underlying mechanism involved the activation of the CD95-triggered apoptosis ${ }^{(71)}$. Interestingly, however, it has been recently reported that also taxanes may exert their cytotoxic effect through the activation of intracellular oxidative stress ${ }^{(72)}$. Nevertheless, in this case it was not the oxidative stress induced by both PUFA and the taxane, but the decreased expression of Her-2/neu oncoprotein to be invoked by the authors to explain the strong synergistic cytotoxic effect exerted by DHA. The effect was visible also in the taxane-resistant SK-BR-3 and BT-474 breast cancer cells ${ }^{(70)}$. Instead, lipid peroxidation and oxidative stress were suggested again to be responsible for the reduced viability of SK-BR-3 cells treated with EPA in combination with $\mathrm{As}_{2} \mathrm{O}_{3}^{(73)}$.

In some studies on breast cancer cells, $n$-3 PUFA were chemically conjugated with other drugs in an effort to examine new innovative therapeutic strategies. For instance, in an additional study, Siddiqui et $a l^{(74)}$ synthesised a conjugated EPA or DHA moiety with propofol, and these conjugates were tested in MDA-MB-231 breast cancer cells for their ability to modulate cell migration, adhesion and apoptosis. Propofol (2,6-diisopropylphenol) is the most extensively used anaesthetic-sedative agent possessing the characteristic to be non-toxic to humans also at high levels $(50 \mu \mathrm{g} / \mathrm{ml})$. It has been also reported that concentrations of propofol in the range of $20-50 \mu \mathrm{M}$ possess anticancer properties ${ }^{(75,76)}$. Interestingly, the propofol-DHA or propofol-EPA conjugates ${ }^{(74)}$ were able to significantly inhibit cell adhesion and migration and to induce apoptosis in the cells more than DHA, EPA or propofol alone, but the authors did not investigate the molecular mechanism underlying these effects. Moreover, DHA was recently conjugated with lovastatin ${ }^{(77)}$, and the lovastatin-DHA (LOV-DHA) conjugate was able to induce apoptosis in MDA-MB-231 cells at concentrations as low as $1 \mu \mathrm{m}$. Statins are drugs inhibiting the activity of the enzyme 3-hydroxy-3-methylglutaryl-CoA (HMG-CoA) reductase, a key enzyme in the synthesis of cholesterol $^{(78)}$. They have also been involved in the regulation of cell proliferation, differentiation, apoptosis and invasion ${ }^{(79-81)}$, and they were shown to inhibit the proliferation of different kinds of cancer cells, including breast cancer ${ }^{(82-84)}$. Interestingly, while the addition of mevalonate reversed the effect of lovastatin, it did not modify the growth-inhibitory effects of the LOV-DHA conjugate, suggesting that the conjugate acted through a HMG-CoA reductase-independent pathway ${ }^{(77)}$.

\section{Prostate cancer cells}

A clear molecular mechanistic approach has been used in the studies performed on prostate cancer cells treated with LC- $n-3$ PUFA combined with different drugs, but the mechanisms proposed are highly variable (Table 4). Narayanan et al. ${ }^{(85)}$ 
Table 4. Prostate cancer cells in vitro: effects of $n-3$ PUFA in combination with conventional antineoplastic drugs

\begin{tabular}{|c|c|c|c|c|c|}
\hline Cell type & Antineoplastic drug & $n-3$ PUFA treatment & Anticancer effect(s) & Biochemical and molecular effects & Reference \\
\hline PC-3 & $\mathrm{As}_{2} \mathrm{O}_{3}(1 \mu \mathrm{m})$ & EPA $(100 \mu \mathrm{m})$ & $\downarrow$ Cell viability & $\uparrow$ Lipid peroxidation & 73 \\
\hline LNCaP, DU145, PC-3 & Celecoxib $(2.5 \mu \mathrm{m})$ & $\mathrm{DHA}(2.5 \mu \mathrm{m})$ & $\begin{array}{l}\uparrow \text { Cell growth inhibition } \\
\uparrow \text { Apoptosis induction }\end{array}$ & $\begin{array}{l}\downarrow \text { COX-2 and NF-kB p65 expression } \\
\uparrow \text { Caspase-3, Bax, PPARy and RXR expression }\end{array}$ & 85 \\
\hline I-26 & Celecoxib $(2.5 \mu \mathrm{m})$ & $\mathrm{DHA}(2.5 \mu \mathrm{M})$ & $\uparrow$ Cell growth inhibition & $\begin{array}{l}\uparrow \text { hsp70 } \\
\uparrow p 53\end{array}$ & 86 \\
\hline LNCaP, DU145, PC3 & Docetaxel $(0.6 \mathrm{~nm})$ & $\mathrm{DHA}(12 \cdot 5-50 \mu \mathrm{m})$ & $\begin{array}{l}\uparrow \text { Cytotoxicity, } \\
\uparrow \text { Apoptosis induction } \\
\uparrow \text { Cell cycle arrest }\end{array}$ & $\begin{array}{l}\downarrow \text { NF-KB signalling } \\
\downarrow \text { FADD, AKT1, MAX } \\
\downarrow \text { TRAF3, MAP2k4 expression }\end{array}$ & 89 \\
\hline
\end{tabular}

COX-2, cyclo-oxygenase-2; RXR, retinoid X receptor; FADD, Fas-associated death domain-containing protein; AKT1, protein kinase B1; TRAF3, TNF receptor-associated factor 3; MAP2k4, mitogen-activated protein kinase kinases 4.

found that a combination of DHA and celecoxib at low doses ( $2.5 \mu \mathrm{m}$ each) powerfully prevented prostate cancer cell growth. The authors suggested that DHA could exert its effect through the modulation of COX-2, NF- $\kappa \mathrm{B}$, the nuclear receptors PPAR- $\gamma$ and retinoid $\mathrm{X}$ receptor, all these factors being involved in prostate carcinogenesis ${ }^{(85)}$. The effects induced by DHA/celecoxib were significantly higher than those obtained with the two compounds given alone, even at higher concentrations. In an additional study, these authors ${ }^{(86)}$ found that DHA in combination with celecoxib was also able to increase Hsp70 levels and p53 transport into the nucleus in prostate cancer cells, thus providing an additional COX-2-independent anti-tumour mechanism. This effect of DHA is in line with what has been observed in previous studies, which had revealed that the increased expression of heat shock protein isoforms could induce anti-tumour activities in the presence of wild-type $\mathrm{p} 53^{(87,88)}$.

Interestingly, the down-regulation of NF-кB-related genes was reported in either hormone receptor-positive or -negative LNCaP, DU145 and PC3 cells treated with DHA and docetaxel, and it was associated with the synergistic induction of apoptosis by the two compounds $^{(89)}$. This kind of combination is of great interest, since the results of two recent clinical trials have shown taxanes, docetaxel in particular, to be highly efficient drugs for the therapy of advanced and hormone-refractory prostate cancer ${ }^{(90,91)}$. However, docetaxel is cytotoxic and can induce deleterious side effects, such as myelosuppression and granulocytopenia, which limit the dose that can be administered to patients ${ }^{(92)}$. Thus, it could be hypothesised that the combined treatment with DHA could allow a decrease in the doses of docetaxel, but still to obtain the growthinhibitory effects obtained with higher doses.

\section{Leukaemia, lymphoma and myeloma cells}

Similarly to what was observed in breast cancer cells, the main molecular mechanisms proposed in most of the papers investigating anti-neoplastic agents/LC- $n$ - 3 PUFA combinations in leukaemia, lymphoma and myeloma cells are enhanced cellular oxidative stress and lipid peroxidation (Table 5 and Table 6). In one of these studies ${ }^{(93)}, n-3$ PUFA have been combined with $\mathrm{As}_{2} \mathrm{O}_{3}$, which possesses a broad spectrum of antileukaemic activity due to its ability to induce apoptosis via intracellular production of $\operatorname{ROS}^{(94)}$. Since this compound is not effective at the same degree in all types of leukaemic cells, the search for agents enhancing $\mathrm{As}_{2} \mathrm{O}_{3}$ efficacy has recently gained great interest. In this study, Sturlan et al. ${ }^{(93)}$ observed that DHA is able to enhance cytotoxicity of $\mathrm{As}_{2} \mathrm{O}_{3}$ in HL-60 cells through the induction of apoptosis, and the effect was ascribed to the synergism of the two combined agents in producing intracellular ROS and toxic lipid peroxidation products. In fact, the enhanced efficacy of the combination was abolished by treatment with vitamin $\mathrm{E}$ or by the substitution of DHA with oleic acid (a non-peroxidisable FA) ${ }^{(93)}$. Other studies confirmed the synergistic cytotoxic effect of this combination in leukaemic as well as in solid tumour cells ${ }^{(73,95)}$. It is important to underline that in one of these studies ${ }^{(95)}$, where DHA was used in combination not only with $\mathrm{As}_{2} \mathrm{O}_{3}$, but also IFN- $\gamma$ and emodin, clinically achievable doses of DHA and emodin allowed reduction in As concentrations by 100-fold, preserving high toxicity in tumour cells ${ }^{(95)}$. Similarly, enhanced cytotoxicity was observed and the pro-oxidant mechanism was invoked in a range of leukaemia or lymphoma cells when DHA was used in combination with other antineoplastic drugs (adriamycin, methotrexate, doxorubicin, dexamethasone, mitomycin and imatinib) ${ }^{(96-99)}$. Similarly, it was shown ${ }^{(100)}$ that treatments with EPA or DHA enhanced the sensitivity of the B-leukaemic cell lines to the cytotoxic effect of doxorubicin, vincristine and fludarabine by promoting their arrest in the cell cycle $G_{2} / M$ phase and inducing their death.

Another combination recently investigated in lymphoma cells was hyperthermia together with $n-3^{(101)}$. Hyperthermia has been used as an anticancer therapeutic strategy for several years ${ }^{(102)}$, but an important limitation of this treatment is that it often does not sufficiently kill neoplastic cells. In their paper, Cui et $a l{ }^{(101)}$ showed that combining hyperthermia $\left(44^{\circ} \mathrm{C}\right.$ for $10 \mathrm{~min}$ ) with treatment with $20 \mu \mathrm{m}-\mathrm{DHA}$ induced significant apoptosis in human myelomonocytic lymphoma U937 cells. Again, increased ROS production, together with mitochondria dysfunction, and protein kinase $\mathrm{C}-\delta$ activation were shown to be the mechanisms underlining the effects of this combination.

To finish, it is noteworthy, in the recent remarkable finding of Abdi et $a l .{ }^{(103)}$, that $n$-3 PUFA are able to sensitise also multiple myeloma cells to bortezomib. Multiple myeloma is a malignant neoplasm of terminally differentiated $\mathrm{B}$ cells infiltrating the bone marrow, and most patients, even when treated with more innovative drugs such as this one, develop intrinsic drug resistance or become chemoresistant in the course of treatment. Both primary cells from myeloma patients and different human myeloma cell lines have been shown to develop resistance to bortezomib ${ }^{(104,105)}$. 
Table 5. Leukaemia cells in vitro: effects of $n-3$ PUFA in combination with conventional antineoplastic drugs

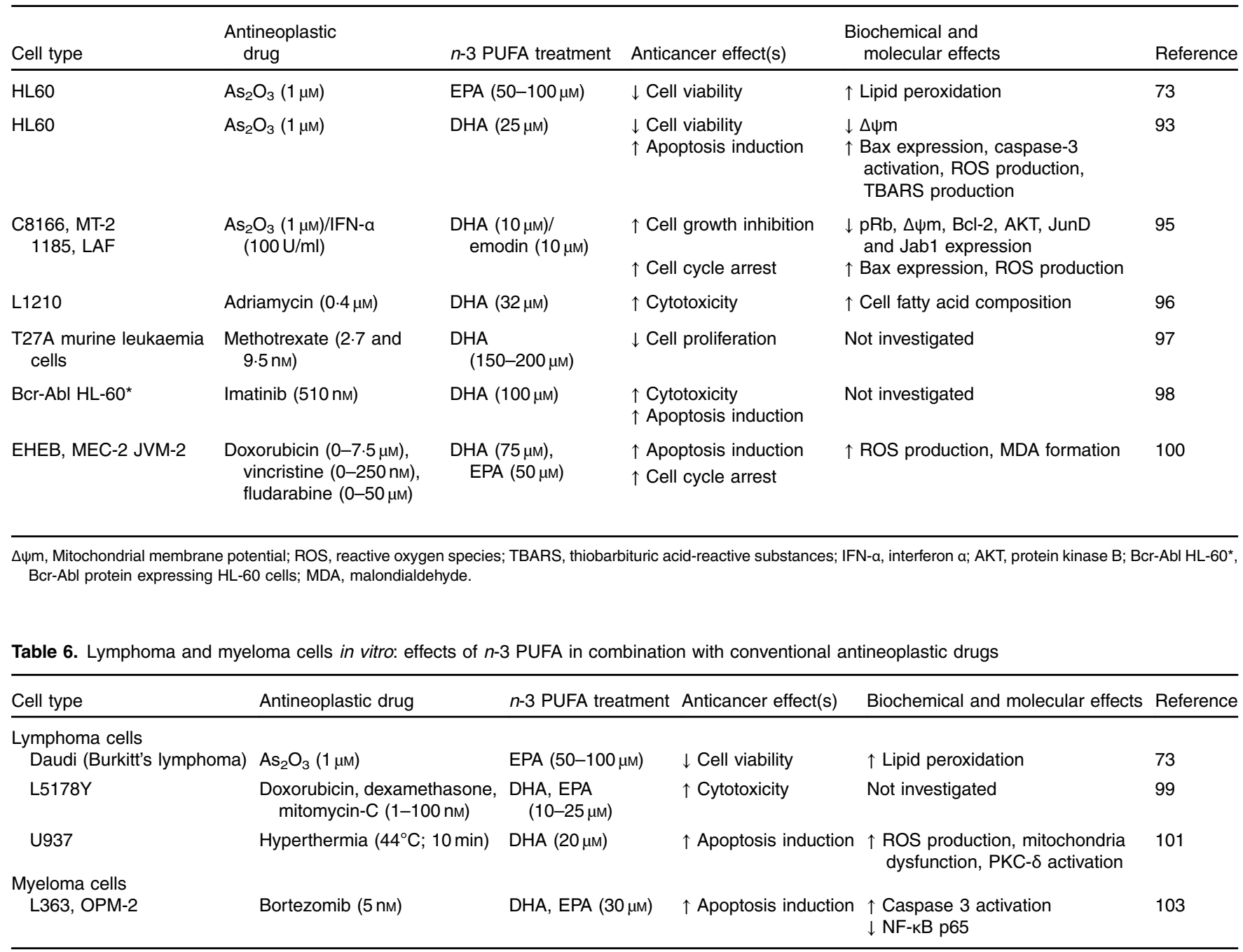

ROS, reactive oxygen species; PKC- $\delta$, protein kinase $C \delta$.

The mechanism of antineoplastic action of bortezomib in multiple myeloma involves the inhibition of the NF- $\kappa B$ signalling pathway ${ }^{(106)}$, and many reports have demonstrated a marked suppression of this pathway by $n-3 \mathrm{PUFA}^{(107)}$. As a matter of fact, it was found that EPA and DHA affected multiple signalling pathways in multiple myeloma cells, including NF- $\kappa \mathrm{B}$, Notch, Hedgehog, oxidative stress and Wnt ${ }^{(103)}$. Finally, it is worth noticing also that EPA and DHA enhanced the sensitivity of multiple myeloma cells to bortezomib but did not affect the viability of normal peripheral mononuclear cells.

\section{Other kinds of cancer cells}

Besides the studies performed in colon, breast and prostate cancer cells, and in leukaemia, lymphoma and myeloma cells, only a few studies have been performed in cells deriving from other tissues (Table 7). Most of these studies also showed that the synergistic cytotoxic effect of conventional antineoplastic agents and LC- $n-3$ PUFA combined together could be explained on the basis of their pro-oxidant effect. For instance, a significant cytotoxic effect mediated through enhanced lipid peroxidation and ROS production was observed in drug-resistant neuroblastoma cells treated with $n-3$ PUFA in combination with several antineoplastic drugs, such as vincristine ${ }^{(108)}, \mathrm{As}_{2} \mathrm{O}_{3}$, cisplatin, doxorubicin and irinotecan ${ }^{(109)}$. Similarly, increased oxidative stress-dependent cytotoxicity was observed ${ }^{(110)}$ in glioblastoma and bronchial carcinoma cells treated with combinations of DHA and doxorubicin. However, in a more recent study ${ }^{(111)}$ specific oligo-array analyses demonstrated that the enhanced effectiveness of etoposide administered in combination with DHA to brain tumour cells (medulloblastoma and glioblastoma) was related to a markedly reduced expression of several genes involved in cell proliferation, survival, invasion, DNA damage repair and angiogenesis. Conversely, in agreement with the oxidative stress hypothesis, it has been recently shown that EPA is able to sensitise U251 human glioblastoma cells to radiation by a mechanism involving an enhancement of lipid peroxidation in treated cells ${ }^{(112)}$.

Moreover, a synergistic activity of DHA and COX-2 inhibitors (celecoxib and indomethacin) combinations was observed ${ }^{(113)}$ 


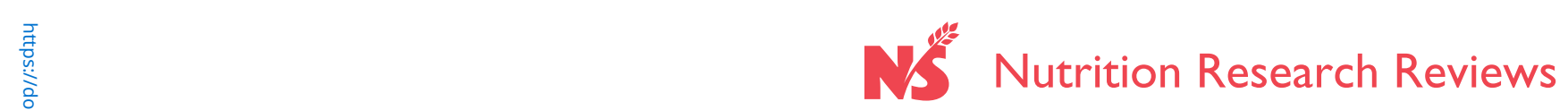

Table 7. Cancer cells of different origin* in vitro: effects of $n$-3 PUFA in combination with conventional antineoplastic drugs

\begin{tabular}{|c|c|c|c|c|c|}
\hline Cell type & Antineoplastic drug & $\begin{array}{l}n-3 \text { PUFA } \\
\text { treatment }\end{array}$ & Anticancer effect(s) & $\begin{array}{l}\text { Biochemical and molecular } \\
\text { effects }\end{array}$ & Reference \\
\hline HeLa cervical adenocarcinoma cells & Hypericin (150 nм); PDT (3.15 mW/cm²) & $\mathrm{DHA}(100 \mu \mathrm{m})$ & $\begin{array}{l}\uparrow \text { Cytotoxicity } \\
\uparrow \text { Apoptosis induction }\end{array}$ & $\begin{array}{l}\uparrow \text { ROS production } \\
\uparrow \text { Lipoperoxidation }\end{array}$ & 54 \\
\hline SKOV-3 ovarian cancer cells & $\mathrm{As}_{2} \mathrm{O}_{3}(1 \mu \mathrm{m})$ & EPA $(100 \mu \mathrm{m})$ & $\downarrow$ Cell viability & $\uparrow$ Lipid peroxidation & 73 \\
\hline NCG, NCG/VCR1* neuroblastoma cells & Vincristine $(1-100 \mathrm{ng} / \mathrm{ml})$ & $\begin{array}{l}\mathrm{DHA}(10-50 \mu \mathrm{g} / \\
\mathrm{ml})\end{array}$ & $\uparrow$ Cytotoxicity & $\begin{array}{l}\uparrow \text { Lipid peroxidation } \\
\uparrow \text { Vincristine cell uptake }\end{array}$ & 108 \\
\hline $\begin{array}{l}\text { SK-N-DZ, SH-SY5Y, SKN-BE(2), SK-N-AS, } \\
\text { IMR-32 neuroblastoma cells }\end{array}$ & $\begin{array}{l}\text { Cisplatin }(0.5-3 \mu \mathrm{m}) ; \\
\text { doxorubicin }(2-20 \mathrm{ng} / \mathrm{ml}) ; \text { irinotecan } \\
(0 \cdot 2-2 \mu \mathrm{g} / \mathrm{ml}) ; \text { diclofenac }(100 \mu \mathrm{m}) ; \\
\mathrm{As}_{2} \mathrm{O}_{3}(1 \mu \mathrm{M})\end{array}$ & DHA $(25-150 \mu \mathrm{m})$ & $\begin{array}{l}\uparrow \text { Cytotoxicity } \\
\uparrow \text { Apoptosis induction }\end{array}$ & $\begin{array}{l}\uparrow \text { ROS production } \\
\uparrow \Delta \psi \mathrm{m}\end{array}$ & 109 \\
\hline $\begin{array}{l}\text { A-172, U-87 glioblastoma cells, A- } 427 \\
\text { bronchial carcinoma cells }\end{array}$ & Doxorubicin $(0.5 \mu \mathrm{M})$ & DHA $(30 \mu \mathrm{m})$ & $\uparrow$ Cytotoxicity & $\begin{array}{l}\uparrow \text { Lipid peroxidation (only in } \\
\text { A-427 cells) }\end{array}$ & 110 \\
\hline Daoy, D283 medulloblastoma cells & Etoposide $(0.2-1.6 \mu \mathrm{M})$ & DHA $(15-60 \mu \mathrm{m})$ & $\begin{array}{l}\uparrow \text { Cytotoxicity } \\
\downarrow \text { Cell proliferation }\end{array}$ & $\begin{array}{l}\downarrow \text { PRKDC, survivin, PIK3R1, } \\
\text { MAPK14, NF-kB1, } \\
\text { NF-KBIA, BCL2, CD44, } \\
\text { MAT1 expression }\end{array}$ & 111 \\
\hline U251 glioblastoma cells & Radiation (2 Gy/min) & EPA $(30 \mu \mathrm{M})$ & $\uparrow$ Cytotoxicity & $\uparrow$ Lipid peroxidation & 112 \\
\hline A375 skin melanoma cells & $\begin{array}{l}\text { Celecoxib }(20 \mu \mathrm{m}), \text { indomethacin }(20 \mu \mathrm{M}), \\
\quad \text { piroxicam }(40 \mu \mathrm{M}), \text { aspirin }(480 \mu \mathrm{m})\end{array}$ & DHA (160 pм) & $\uparrow$ Cytotoxicity & Not investigated & 113 \\
\hline Sgc7901 gastric carcinoma cells & $5-\mathrm{FU}(40 \mu \mathrm{g} / \mathrm{ml})$ & $\mathrm{DHA}(40 \mu \mathrm{g} / \mathrm{ml})$ & $\begin{array}{l}\uparrow \text { Growth inhibition } \\
\uparrow \text { Apoptosis induction }\end{array}$ & $\begin{array}{l}\uparrow \text { Bax mRNA expression } \\
\downarrow \text { FAS, BCL-2, BCL2L12, } \\
\text { caspase-9 mRNA } \\
\text { expression }\end{array}$ & 114 \\
\hline
\end{tabular}

PDT, photodynamic therapy; ROS, reactive oxygen species; NCG/NCR1, vincristine-resistant NCG cells; $\triangle 4 \mathrm{~m}$, mitochondrial membrane potential; PRKDC, protein kinase, DNA-activated, catalytic polypeptide; PIK3R1, phosphoinositide3-kinase, regulatory subunit 1; MAPK14, mitogen-activated protein kinase 14; NF-kB1, NF-kB light polypeptide gene enhancer in B-cells 1; NF-kBIA, NF-kB inhibitor a; 5-FU, 5-fluorouracil; FAS, fatty acid synthase.

* Other than colon, breast, prostate, leukaemia, lymphoma and myeloma cells. 
in human melanoma cells. Similarly, the synergism of 5-FU and DHA combination was reported in human gastric carcinoma cells $^{(114)}$, where the combination induced apoptosis by modulating the expression of several apoptosis-related factors, including Bax, Fas, Bcl-2, Bcl2L12 and caspase-9.

On the whole, it can be concluded that most of the studies investigating the beneficial effects of $n-3$ PUFA in combination with antineoplastic agents in vitro indicate increased lipid peroxidation and oxidative stress as the main mechanisms involved. Other studies, however, and mainly the most recent ones, identified also other more specific molecular pathways. Certainly, the possibility that the oxidative stress-related cytotoxicity induced by $n-3$ PUFA may exalt the effect of antineoplastic agents that by themselves are inducers of oxidative stress (doxorubicine, taxanes, radiation) is easy to understand. However, in our opinion, it would be recommendable, when investigating mechanisms in vitro, not to use high concentrations of $n-3$ PUFA (i.e. concentrations that are able to produce maximal or near-maximal cytotoxicity) to avoid cytotoxicity exclusively related to necrosis due to high levels of oxidative stress. Conversely, low levels of ROS production and oxidative stress may function as specific intracellular signals that may induce plenty of cellular pathways involved in apoptosis, differentiation, autophagy and other cellular processes related to cell growth. Moreover, in future studies it would be important to focus also on specific effects that $n$ - 3 PUFA may exert on molecular pathways already involved in the sensitivity or resistance to specific antineoplastic agents used in the combinations under study.

\section{In vivo animal studies}

A great effort has also been expended in studying the efficacy of $n-3$ PUFA in combination with conventional antineoplastic drugs in animal models. We will analyse in the two following paragraphs the results obtained by the animal models mainly used, that is, human cancer cells transplanted in nude mice (or murine tumours transplanted in syngeneic rats or mice), and chemically induced carcinogenesis in rats.

\section{Cancer cells transplanted in animals}

Several studies have contributed to demonstrate that the addition of FO or LC- $n$ - 3 PUFA to the diet of animals following tumour transplantation increases the efficacy of conventional cancer chemotherapy. Most of them were performed using human breast cancer cells xenografted in nude mice (Table 8), and associated the decreased tumour rate with an altered oxidative status and increased lipid/protein peroxidation ${ }^{(115-117)}$ (for further details, see Table 8). In some of the studies ${ }^{(118,119)}$ the mechanisms underlying the improved anti-tumour effect of the combination studied were not investigated. However, in another study ${ }^{(120)}$ performed by combining cyclophosphamide and a FO (menhaden oil) it was observed that the improved anti-tumour effect was related to the increased activity of one of the key cyclophosphamide-activating enzymes, CYP2B1, found significantly enhanced in the liver and tumour of menhaden oil-treated animals. It was suggested that this effect could be related to the formation of more pharmacologically active drug metabolites that could enhance cyclophosphamide anti-tumour response. Interestingly, FO-containing diets were also found to reduce deleterious intestinal, haematological and cardiac side effects of various chemotherapeutic treatments ${ }^{(120-122)}$. It has also been shown that the chemical binding of the $n-3$ PUFA linolenic acid to the moiety of one of the chemotherapic drugs (doxorubicin) confers to it tumour specificity ${ }^{(123)}$, thus making linolenic acid a good candidate for possible use as a targeting molecule also for other chemotherapic agents.

The remaining in vivo transplantation models were mostly performed by injecting murine colon and lung cancer cells, or murine leukaemia cells in syngeneic animals treated with FO or $\mathrm{EPA}$ and/or $\mathrm{DHA}^{(124-130)}$ (Table 9). Again, in two of these studies $^{(127,128)}$ enhanced oxidative stress and lipid peroxidation were involved, and several other studies ${ }^{(124-126)}$ were only observational and, even though they found a positive effect of n-3 PUFA combined with epothilone, 5-FU, cyclophosphamide, doxorubicin or arabinosylcytosine, they did not investigate the possible molecular mechanisms involved.

An interesting therapeutic approach was the covalent binding of DHA to different anti-tumour drugs. In a model of implanted lung cancer DHA was covalently conjugated to paclitaxel ${ }^{(131)}$. The conjugate, besides being less toxic with respect to paclitaxel alone, was able to induce a complete tumour regression, while paclitaxel alone induced only a partial regression. Since DHA-paclitaxel remained in tumours for long times at high concentrations, and it was slowly converted to the cytotoxic metabolites of paclitaxel, it was suggested that the conjugate could also kill residual tumour cells that eventually re-enter the cell cycle. Similarly, an enhanced tumour sensitivity was observed by Wang et al. ${ }^{(132)}$ when 10-hydroxycamptothecin was conjugated with DHA and administered to mice bearing Lewis lung carcinoma, L1210 leukaemia and 38 adenocarcinoma cells.

\section{Chemically induced carcinogenesis}

The possible adjuvant effect of $n-3$ PUFA in the therapy of breast cancer has been investigated also using the $N$-methylnitrosourea-induced carcinogenesis model in rats (Table 10). These studies were performed using radiation or drugs that act mainly through a pro-oxidant effect, and this is probably the reason why the main mechanisms found to be associated with the enhanced anti-tumour effects induced by $n$ - 3 PUFA were the altered oxidative status and/or lipid peroxidation ${ }^{(133-136)}$. It should be noted that this mechanism was observed either treating the animals with quite low doses of $n$ - 3 PUFA (about $0.7 \mathrm{~g} / \mathrm{d}$ DHA, see Colas et al. $\left.{ }^{(133)}\right)$, or with doses several times higher (about $4.5 \mathrm{~g} / \mathrm{kg} \mathrm{EPA}+\mathrm{DHA}$, present in the dose of FO administered by Manni et $a l^{(134,137)}$ (see United States Environmental Protection Agency ${ }^{(138)}$ for the calculation of the exact doses of LC- $n$-3 PUFA administered).

The hypothesis that a pro-oxidant mechanism was involved also when $n-3$ PUFA were supplemented in combination with radiation $^{(135)}$ was also supported by the finding that the addition of vitamin $\mathrm{E}$ to the DHASCO diet inhibited the beneficial effect of DHA in rats bearing breast cancer ${ }^{(135)}$. In a more recent study ${ }^{(137)}$ performed by supplementing FO alone or in 
Table 8. Animals implanted with cancer cells: effects of $n-3$ PUFA in combination with conventional antineoplastic drugs

\begin{tabular}{|c|c|c|c|c|c|c|}
\hline Cell type & Animal model & Antineoplastic drug & $n$-3 PUFA treatment & Anticancer effect(s) & $\begin{array}{l}\text { Biochemical and molecular } \\
\text { effects }\end{array}$ & Reference \\
\hline $\begin{array}{l}\text { MDA-MB } 231 \text { human } \\
\text { breast carcinoma cells }\end{array}$ & $\begin{array}{l}\text { Athymic nude mice } \\
\text { (injected s.c.) }\end{array}$ & $\begin{array}{l}\text { ET-18-OCH3 }(10 \mathrm{mg} / \mathrm{kg} \text { body } \\
\text { weight injected s.c. three } \\
\text { times per week for } 2 \text { weeks) }\end{array}$ & $\begin{array}{r}\text { FO (19\% in the diet for } 2 \text { weeks } \\
\text { before ET-18-OCH3 treatment) }\end{array}$ & $\begin{array}{l}\downarrow \text { Tumour growth rate } \\
\uparrow \text { Cytotoxicity }\end{array}$ & $\uparrow$ Lipid peroxidation & 115 \\
\hline $\begin{array}{l}\text { MDA-MB } 231 \text { human } \\
\text { breast carcinoma cells }\end{array}$ & $\begin{array}{l}\text { Athymic nude mice } \\
\text { (injected s.c.) }\end{array}$ & $\begin{array}{l}\text { Doxorubicin }(5 \mathrm{mg} / \mathrm{kg} \text { body } \\
\text { weight every } 4 \mathrm{~d} \text { i.v. })\end{array}$ & $\begin{array}{c}\text { FOC ( } 3 \% \text { in the diet, consisting } \\
\text { of } 34 \% \text { EPA, } 24 \% \text { DHA, and } \\
10 \% \text { of other } n-3 \text { fatty acids, } \\
2 \text { weeks before and for all the } \\
\text { duration of the experiment) }\end{array}$ & $\downarrow$ Tumour growth rate & $\begin{array}{l}\uparrow \text { Lipid peroxidation } \\
\downarrow \text { GPx:SOD ratio }\end{array}$ & 116 \\
\hline $\begin{array}{l}\text { MX-1 human breast } \\
\text { carcinoma }\end{array}$ & $\begin{array}{l}\text { Balb/c nul + mice } \\
\quad \text { (transplanted s.c.) }\end{array}$ & $\begin{array}{l}\text { Mitomycin C }(0.5 \mathrm{mg} / \mathrm{kg} \text { body } \\
\text { weight i.p., once per week } \\
\text { for } 4 \text { weeks) }\end{array}$ & $\begin{array}{l}\text { Menhaden oil ( } 20 \% \text { in the diet, } \\
\text { for } 20 \mathrm{~d} \text { before tumour } \\
\text { transplantation) }\end{array}$ & $\begin{array}{l}\downarrow \text { Tumour growth rate } \\
\downarrow \text { Mitomycin toxicity }\end{array}$ & $\begin{array}{l}\uparrow \text { Lipid and protein } \\
\text { peroxidation } \\
\uparrow \text { CAT, SOD, GPx, GSTPx } \\
\text { activity }\end{array}$ & 117 \\
\hline $\begin{array}{l}\text { MCF-7 human breast } \\
\text { carcinoma cells }\end{array}$ & $\begin{array}{l}\text { Athymic nude mice } \\
\text { (injected s.c.) }\end{array}$ & $\begin{array}{l}\text { Irinotecan }(60 \mathrm{mg} / \mathrm{kg} \text { body } \\
\text { weight, i.v. once each } 4 \mathrm{~d} \\
\text { for } 6 \text { weeks) }\end{array}$ & $\begin{array}{c}\text { FO ( } 3 \text { or } 6 \% \text { in the diet for } 10 \mathrm{~d} \\
\text { before irinotecan treatment) }\end{array}$ & $\begin{array}{l}\downarrow \text { Tumour growth rate } \\
\downarrow \text { Mitotic figures in the } \\
\text { duodenal crypts } \\
\uparrow \text { Apoptotic figures in the } \\
\text { duodenal crypts }\end{array}$ & Not investigated & 118 \\
\hline $\begin{array}{l}\text { MDA-MB } 231 \text { human } \\
\text { breast carcinoma cells }\end{array}$ & $\begin{array}{l}\text { Female SCID mice } \\
\text { (injected s.c.) }\end{array}$ & - & $\begin{array}{l}\text { DOX-LNA ( } 5 \mathrm{mg} / \mathrm{kg} \text { body weight } \\
\text { once when tumour becomes } \\
\text { palpable and after } 7 \mathrm{~d} \text { ) }\end{array}$ & $\begin{array}{l}\downarrow \text { Tumour growth rate } \\
\downarrow \text { Body-weight change } \\
\uparrow \text { Animal survival } \\
\uparrow \text { Drug tumour specificity }\end{array}$ & Not investigated & 119 \\
\hline $\begin{array}{l}\text { MX-1 human breast } \\
\text { carcinoma }\end{array}$ & $\begin{array}{l}\text { Balb/c nul + mice } \\
\text { (transplanted s.c.) }\end{array}$ & $\begin{array}{l}\text { Cyclophosphamide }(72.5 \mathrm{mg} / \\
\mathrm{kg} \text { body weight, as a single } \\
\text { i.p. injection) }\end{array}$ & $\begin{array}{l}\text { Menhaden oil }(20 \% \text { in the diet for } \\
20 \text { d before tumour } \\
\text { transplantation) }\end{array}$ & $\begin{array}{l}\downarrow \text { Tumour growth rate } \\
\downarrow \text { Cyclophosphamide toxicity }\end{array}$ & $\begin{array}{l}\uparrow \text { CYP2B1 activity in liver } \\
\text { and tumour } \\
\uparrow A D H \text { activity in liver }\end{array}$ & 120 \\
\hline
\end{tabular}

s.c., Subcutaneous; FO, fish oil; i.v., intravenous; FOC, fish oil concen
doxorubicin- $a$-linolenic acid conjugate; ADH, alcohol dehydrogenase. 
Table 9. Animals implanted with cancer cells: effects of $n$-3 PUFA in combination with conventional antineoplastic drugs

\begin{tabular}{|c|c|c|c|c|c|c|}
\hline Cell type & Animal model & Antineoplastic drug & $n$-3 PUFA treatment & Anticancer effect(s) & $\begin{array}{l}\text { Biochemical and } \\
\text { molecular effects }\end{array}$ & Reference \\
\hline $\begin{array}{l}\text { MAC16 colon } \\
\text { adenocarcinoma }\end{array}$ & $\begin{array}{l}\text { NMRI mice } \\
\quad \text { (transplanted s.c.) }\end{array}$ & $\begin{array}{l}\text { EPO ( }(2.5 \mathrm{mg} / \mathrm{kg} \text { body weight), } \\
\text { GCB ( } 50 \mathrm{mg} / \mathrm{kg} \text { body weight), } \\
5 \text {-FU ( } 80 \mathrm{mg} / \mathrm{kg} \text { body weight), } \\
\text { CYC ( } 300 \mathrm{mg} / \mathrm{kg} \text { body weight) }\end{array}$ & $\begin{array}{l}\text { EPA ( } 2 \mathrm{~g} / \mathrm{kg} \text { body weight), DHA } \\
\text { ( } 2.25 \mathrm{~g} / \mathrm{kg} \text { body weight })\end{array}$ & $\begin{array}{l}\downarrow \text { Tumour growth rate }(E P O+ \\
\text { DHA; } 5 \text {-FU + EPA or DHA; } \\
\text { CYC + EPA) } \\
\downarrow \text { Cachexia }(5-F U+E P A)\end{array}$ & Not investigated & 124 \\
\hline $\begin{array}{l}\text { A549 human lung cancer } \\
\text { cells }\end{array}$ & Nude mice (injected s.c.) & $\begin{array}{l}\text { Doxorubicin }(3.6 \mathrm{mg} / \mathrm{kg} \text { body } \\
\text { weight at days } 10,15,20 \text { and } \\
25 \text { after initiation of diet) }\end{array}$ & $\begin{array}{l}\text { Menhaden oil ( } 19 \% \text { in the diet, } \\
10 \mathrm{~d} \text { before doxorubicin } \\
\text { treatment) }\end{array}$ & $\downarrow$ Tumour growth rate & Not investigated & 125 \\
\hline L1210 leukaemia cells & BDF1 mice (injected i.v.) & $\begin{array}{l}\text { AraC }(40 \mathrm{mg} / \mathrm{kg} \text { i.p. daily, every } \\
\text { other day for } 10 \mathrm{~d})\end{array}$ & DHA $(1.8 \mathrm{~g} / \mathrm{kg}$ body weight/d) & $\begin{array}{l}\uparrow \text { Life span } \\
\downarrow \text { Drug toxicity }\end{array}$ & Not investigated & 126 \\
\hline Ward colon tumour & $\begin{array}{l}\text { Fisher } 344 \text { rats } \\
\quad \text { (transplanted s.c.) }\end{array}$ & $\begin{array}{l}\text { CPT-11 (50 mg/kg body weight) } \\
5 \text {-FU ( } 50 \mathrm{mg} / \mathrm{kg} \text { body weight) } \\
\text { (once a week for } 2 \text { weeks) }\end{array}$ & $\begin{array}{l}\text { FO (2.3\% in the diet: } 0.64 \% \text { EPA } \\
\text { and } 0.16 \% \text { DHA of total diet, } \\
\text { for } 2 \text { weeks before tumour } \\
\text { transplantation) }\end{array}$ & $\begin{array}{l}\uparrow \text { Tumour chemosensitivity } \\
\downarrow \text { Body-weight loss; anorexia } \\
\uparrow \text { Peripheral leucocyte count } \\
\text { normalisation }\end{array}$ & $\downarrow$ GSH:GSSG ratio & 127 \\
\hline $\begin{array}{l}\text { Lewis lung carcinoma } \\
\text { 3LL }\end{array}$ & C57BL/6J mice & $\begin{array}{l}\text { Cisplatin ( } 3 \mathrm{mg} / \mathrm{kg} \text { body weight } \\
\text { i.v., at day } 1 \text { and } 10 \text { after } \\
\text { tumour resection) }\end{array}$ & $\begin{array}{l}\text { FO ( } 4 \% \text { in the diet, starting } 7 d \\
\text { before tumour inoculation) }\end{array}$ & $\begin{array}{l}\downarrow \text { Tumour development and growth } \\
\downarrow \text { Metastasis burden } \\
\downarrow \text { Anorexia; cachexia }\end{array}$ & $\uparrow$ Lipid peroxidation & 128 \\
\hline Sarcoma 180 cells & Male ICR mice & $\begin{array}{l}\text { 5-FU }(12.5 \mathrm{mg} / \mathrm{kg} \text { per d) orally } \\
\text { administered starting } 12 \mathrm{~h} \text { after } \\
\text { tumour cell implantation for } 14 \mathrm{~d}\end{array}$ & $\begin{array}{l}\text { Carp or tuna oil }(0.2 \text { and } 0.4 \mathrm{ml} / \\
\text { mouse/d) starting } 12 \mathrm{~h} \text { after } \\
\text { tumour cell implantation for } \\
14 \mathrm{~d}\end{array}$ & $\begin{array}{l}\uparrow \text { Tumour growth inhibition } \\
\downarrow \text { Myelotoxicity } \\
\downarrow \text { Body-weight reduction }\end{array}$ & $\begin{array}{l}\uparrow 5 \text {-FU plasma level } \\
\text { (with tuna oil) }\end{array}$ & 129 \\
\hline $\begin{array}{l}\text { SK-NSH neuroblastoma } \\
\text { cells }\end{array}$ & $\begin{array}{l}\text { Male SCID mice } \\
\text { (transplanted s.c. or } \\
\text { orthotopic model) }\end{array}$ & $\begin{array}{l}\text { Sunitinib }(20 \mathrm{mg} / \mathrm{kg} \text { per } \mathrm{d} \text { by oral } \\
\text { administration) }\end{array}$ & $\begin{array}{l}\text { Menhaden oil (10\% in the diet, } \\
3 \text { weeks before tumour } \\
\text { implantation and during } \\
\text { tumour growth) }\end{array}$ & $\begin{array}{l}\downarrow \text { Tumour growth rate } \\
\downarrow \text { Tumour-associated inflammatory } \\
\quad \text { cells } \\
\downarrow \text { Tumour cell proliferation } \\
\downarrow \text { Microvessel density }\end{array}$ & $\begin{array}{l}\uparrow \text { Mitochondrial } \\
\text { dysfunction; tumour } \\
\text { triene/tetraene } \\
\downarrow \text { PLA2 expression }\end{array}$ & 130 \\
\hline
\end{tabular}

s.c., Subcutaneous; EPO, epothilone; GCB, gemcitabine; 5-FU, 5-fluorouracil; CYC, cyclophosphamide; i.v., intravenous;. AraC, arabinosylcytosine; i.p., intraperitoneal; CPT-11, irinotecan; FO, fish oil; GSH, reduced glutathione; GSSG, oxidised glutathione; PLA2, phospholipase A2. 
Table 10. Animal models of experimental carcinogenesis: effects of $n-3$ PUFA in combination with conventional antineoplastic agents

\begin{tabular}{|c|c|c|c|c|c|c|}
\hline Animal model & Carcinogen & Antineoplastic therapy & $n$-3 PUFA treatment & Antineoplastic effect & Molecular mechanism & Reference \\
\hline $\begin{array}{l}\text { Female Sprague-Dawley rats; } \\
\text { mammary carcinogenesis }\end{array}$ & $\begin{array}{l}\text { NMU (a single dose by } \\
\text { s.c. injection, } 25 \mathrm{mg} / \\
\mathrm{kg} \text { body weight) }\end{array}$ & $\begin{array}{l}\text { Epirubicin (i.p. weekly } \\
\text { injection, } 2.5 \mathrm{mg} / \mathrm{kg} \text { for } \\
6 \text { weeks) }\end{array}$ & $\begin{array}{l}\text { DHASCO oil }(1.5 \mathrm{~g} / \mathrm{d} \\
\text { containing } 45 \% \text { of DHA) }\end{array}$ & $\begin{array}{l}\uparrow \text { Tumour regression } \\
\downarrow \text { Tumour vascularisation }\end{array}$ & $\uparrow$ Lipid peroxidation & 133 \\
\hline $\begin{array}{l}\text { Female Sprague-Dawley rats; } \\
\text { mammary carcinogenesis }\end{array}$ & $\begin{array}{l}\text { NMU (a single dose by } \\
\text { i.p. injection, } 50 \mathrm{mg} / \mathrm{kg} \\
\text { body weight) }\end{array}$ & $\begin{array}{l}\text { Tamoxifen }(50-100 \mu \mathrm{g} / \\
\mathrm{kg} \text { body weight, s.c. } \\
\text { injection, } 5 \mathrm{~d} / \text { week })\end{array}$ & FO ( $17 \%$ of the diet) & $\begin{array}{l}\downarrow \text { Tumour development } \\
\downarrow \text { Tumour multiplicity }\end{array}$ & $\downarrow$ GSH oxidation & 134 \\
\hline $\begin{array}{l}\text { Female Sprague-Dawley rats; } \\
\text { mammary carcinogenesis }\end{array}$ & $\begin{array}{l}\text { NMU (a single dose by } \\
\text { S.c. injection, } 25 \mathrm{mg} / \\
\mathrm{kg} \text { body weight) }\end{array}$ & $\begin{array}{l}\text { Radiation (a single } \\
\text { fraction of either } 18, \\
20 \text { or } 22 \text { Gy) }\end{array}$ & DHASCO oil $(40 \%$ of DHA) & $\uparrow$ Tumour regression & $\uparrow$ Lipid peroxidation & 135 \\
\hline $\begin{array}{l}\text { Female Sprague-Dawley rats; } \\
\text { mammary carcinogenesis }\end{array}$ & $\begin{array}{l}\text { NMU (a single dose by } \\
\text { S.c. injection, } 25 \mathrm{mg} / \\
\text { kg body weight) }\end{array}$ & $\begin{array}{l}\text { Epirubicin }(0.8 \mathrm{mg} / \mathrm{kg} \\
\text { once per week for } \\
6 \text { weeks by i.v. } \\
\text { injections into the } \\
\text { tail vein) }\end{array}$ & DHASCO oil $(40 \%$ of DHA) & - & $\begin{array}{l}\uparrow \text { Lipid peroxidation in } \\
\text { tumours but not in normal } \\
\text { tissues }\end{array}$ & 136 \\
\hline $\begin{array}{l}\text { Female Sprague-Dawley rats; } \\
\text { mammary carcinogenesis }\end{array}$ & $\begin{array}{l}\mathrm{NMU} \text { (a single dose by } \\
\text { i.p. injection, } 50 \mathrm{mg} / \mathrm{kg} \\
\text { body weight) }\end{array}$ & $\begin{array}{l}\text { Tamoxifen }(100 \mu \mathrm{g} / \mathrm{kg} \\
\text { body weight, s.c. } \\
5 \mathrm{~d} / \text { week })\end{array}$ & FO ( 10 or $17 \%$ of the diet) & $\begin{array}{l}\downarrow \text { Hyperplasia/carcinoma } \\
\text { transition }\end{array}$ & $\begin{array}{l}\downarrow \text { Ki67 expression } \\
\downarrow \text { 8-Isoprostane levels } \\
\uparrow \text { Gpx activity (with } 10 \% \text { FO) } \\
\uparrow \text { GSH levels (with } 10 \% \text { FO) }\end{array}$ & 137 \\
\hline $\begin{array}{l}\text { Female Sprague-Dawley rats; } \\
\text { mammary carcinogenesis }\end{array}$ & $\begin{array}{l}\text { NMU (a single dose by } \\
\text { s.c. injection, } 25 \mathrm{mg} / \\
\text { kg body weight) }\end{array}$ & $\begin{array}{l}\text { Doxorubicin }(0.5 \mathrm{mg} / \mathrm{kg} \\
\text { twice per week by i.v. } \\
\text { injections into the } \\
\text { tail vein) }\end{array}$ & $\begin{array}{l}\text { DHASCO oil }(2 \mathrm{~g} / \mathrm{d} ; 40 \% \text { of } \\
\text { DHA) }\end{array}$ & $\begin{array}{l}\downarrow \text { Doxorubicin-induced } \\
\text { weight loss }\end{array}$ & Not investigated & 139 \\
\hline
\end{tabular}

NMU, N-methylnitrosourea; s.c., subcutaneous; i.p., intraperitoneal; FO, fish oil; GSH, reduced glutathione; i.v., intravenous; GPx, glutathione peroxidise. 
combination with tamoxifen the authors evaluated systemic and preneoplastic mammary gland biomarkers known to play a key role in the progression to invasive cancer. They found that the FO-rich diets significantly reduced Ki67 expression in hyperplastic lesions, but in this case it was found that dietary FO and/or tamoxifen did not modify systemic oxidative stress biomarkers or lipid peroxidation. On the other hand, the authors observed that in the FO-fed rats the tissue levels of 8 -isoprostane were even markedly reduced. Thus, they hypothesised that the effect was related to the FO-induced AA depletion in the mammary gland, and suggested that the protective effect of $n$-3 PUFA in this experimental model was not mediated by changes in the levels of oxidative stress but by the suppression of AA-specific pathways ${ }^{(137)}$

Moreover, in a study ${ }^{(139)}$ a DHA-enriched diet was reported to significantly reduce the doxorubicin-induced body weight loss, a finding very frequently observed in cancer patients with advanced disease and associated with a poor prognosis.

In conclusion, our recommendation for future combination studies in animals is to choose $n$ - 3 PUFA doses placed in the lower range $(2-8 \mathrm{~g} / \mathrm{kg}$ body weight $\mathrm{EPA}+\mathrm{DHA})$ of all the dosages used so far ${ }^{(140)}$. As a matter of fact, we recently examined $^{(140)}$ all the doses of $n-3$ PUFA used in animal studies and concluded that, in more recent times, similarly to what happened for the clinical studies, there has been a tendency to use doses comprised in the lower range. These lower doses do not induce tissue cytotoxicity and necrosis, often driven by high levels of lipid peroxidation and oxidative stress, but could modulate in a more specific way crucial molecular pathways/ receptors related to inflammation, cell growth, differentiation, angiogenesis and cell invasion ${ }^{(140)}$.

\section{Clinical studies}

Despite the strong evidences of the beneficial antineoplastic effect of $n-3$ PUFA in combination with conventional antineoplastic agents both in cell culture and animal studies, the number of clinical trials performed so far is still extremely small (Table 11, Table 12 and Table 13). We are not examining here the possible reasons as for why more clinical trials have not been performed, having comprehensively discussed this important topic in several previous reviews of ours ${ }^{(141,142)}$. Moreover, besides the scarce number, most of the trials performed so far did not address the possible ability of $n$-3 PUFA to increase the efficiency of the drug/radiation therapy administered simultaneously. On the contrary, they investigated the potential of the dietary $n$-3 PUFA supplementations to reduce cachexia in advanced stages of cancer, or the toxic side-effects of the antineoplastic treatments. For instance, four clinical studies ${ }^{(143-146)}$ conducted in patients with advanced non-small cell lung cancer (NSCLC) fall in this category. The first one ${ }^{(143)}$ (Table 11) was a double-blind study conducted in stage III NSCLC patients receiving a multimodality treatment in order to investigate the effects of an oral nutritional supplement containing both EPA and DHA on nutritional status and inflammatory markers in patients. The results were promising, since the oral $n$-3 PUFA-containing supplement resulted in the preservation of body weight and fat-free mass during chemotherapy (Table 11). The effects were directly related to the supplementation, since this effect was particularly evident in those patients showing an increased plasma phospholipid EPA concentration, which was assessed as an objective marker of compliance with the intervention. Moreover, the n-3 PUFAsupplemented group showed lower levels of the circulating pro-inflammatory cytokine IL-6. Similar results were obtained in another multicentre, randomised, double-blind trial ${ }^{(144)}$ where NSCLC patients undergoing chemotherapy were treated with an oral supplementation of EPA and DHA for about 2 months. Also in this case $n$ - 3 PUFA exerted anti-inflammatory effects by inducing a progressive decrease in C-reactive protein (CRP) and IL-6 levels during chemotherapy. Moreover, they inhibited the formation of ROS and lipid peroxidation products taking place in plasma during chemotherapy. Another human study ${ }^{(145)}$, performed in patients with NSCLC from the time of initiation to the completion of first-line chemotherapy, evaluated the effects of intervention with an oral supplementation with FO (or gelatin capsules containing the same amount of EPA present in the FO) in combination with standard chemotherapy (carboplatin/ vinorelbine or carboplatin/gemcitabine). Body weight, skeletal muscle and adipose tissue were examined (Table 11), and it was demonstrated that the patients in the FO/EPA group were able to maintain their body weight, while the control group showed an average weight loss of $2.5 \mathrm{~kg}$ throughout the chemotherapy period. Also in this case, patients showing the highest increase in plasma EPA concentration after supplementation had the greatest gain in muscle mass. Only one study in patients with advanced NSCLC ${ }^{(146)}$ had the objective to evaluate whether combining chemotherapy (carboplatin with vinorelbine or gemcitabine) with a dietary supplementation with FO could increase the effect of chemotherapy. It was observed that in the FO patients the chemotherapy efficiency increased, as demonstrated by the significant increase in the One-Year Survival Index and in the two parameters Response Rate and Clinical Benefit (both calculated on the basis of the complete response, partial response, and stable disease after four cycles of chemotherapy). An analogous trial ${ }^{(147)}$ was performed in patients diagnosed with stage IV colorectal cancer receiving standard chemotherapy and supplemented with EPA (Table 11). It had the primary goal to evaluate if the dietary EPA could avoid the side effects of the therapy. Thus, the patients were assessed for their nutritional status, dietary intake and chemotherapy compliance. In this case, even though we have to underline that the sample of patients enrolled was very small (thirteen patients in total), the results unequivocally showed that only those receiving the EPA supplement significantly increased their body weight. Instead, the evaluation of their quality of life remained unchanged. Interestingly, however, the patients receiving only the standard chemotherapy had to interrupt the treatment for its high toxicity, whereas the EPA-supplemented group continued the treatment, thus suggesting the positive effect of EPA on chemotherapy tolerability. Nevertheless, for the very small number of patients, this study would need confirmation by a larger controlled randomised trial.

Beneficial effects on the general health conditions of cancer patients dietary supplemented with FO in combination with standard chemotherapy after surgical removal of several kinds 
Table 11. Human clinical trials: effects of $n-3$ PUFA in combination with conventional antineoplastic drugs

\begin{tabular}{|c|c|c|c|c|c|}
\hline Patients and type of study & Antineoplastic treatment(s) & $n$-3 PUFA treatment & Primary endpoint & Effects & Reference \\
\hline $\begin{array}{l}\text { Stage III NSCLC patients ( } n \text { 40) } \\
\text { Randomised double-blind placebo- } \\
\text { controlled trial }\end{array}$ & $\begin{array}{l}\text { Two courses of induction CIS } \\
\text { chemotherapy, six-weekly courses } \\
\text { of DTX and CIS, or two courses of } \\
\text { induction chemotherapy and } \\
\text { concurrent BV } \\
\text { Concurrent thoracic radiotherapy: } \\
1.8-2 \text { Gy (five fractions/week) up } \\
\text { to a maximum of } 45 \text { Gy/patient }\end{array}$ & $\begin{array}{l}\text { Oral nutritional supplement } \\
\text { containing } 2.02 \mathrm{~g} \mathrm{EPA} \mathrm{+} \\
0.92 \mathrm{~g} \mathrm{DHA} / \mathrm{d}\end{array}$ & $\begin{array}{l}\text { Nutritional status and } \\
\text { inflammatory markers }\end{array}$ & $\begin{array}{l}\uparrow \text { Weight maintenance } \\
(P<0.05) \\
\uparrow \text { Maintenance of fat-free } \\
\quad \text { mass }(P<0.05) \\
\uparrow \text { Mid-upper arm } \\
\quad \text { circumference }(P=0.06) \\
\downarrow \text { REE }(P=0.01) \\
\downarrow \text { IL-6 }(P=0.08)\end{array}$ & 143 \\
\hline $\begin{array}{l}\text { Patients with advanced inoperable } \\
\text { NSCLC ( } n \text { 27) } \\
\text { Double-blind placebo-controlled trial }\end{array}$ & $\begin{array}{l}\text { Three courses of chemotherapy with } \\
\text { CIS and GCB to the following } \\
\text { schedule: baseline, after } 8 d, 22 \mathrm{~d} \\
\text { and after } 66 \mathrm{~d}\end{array}$ & $\begin{array}{l}\text { Capsules containing } 510 \mathrm{mg} \text { EPA } \\
\text { and } 340 \mathrm{mg} \text { DHA for } 66 \mathrm{~d}\end{array}$ & $\begin{array}{l}\text { Inflammatory condition and } \\
\text { oxidative and nutritional status }\end{array}$ & $\begin{array}{l}\uparrow \text { Body weight }(P<0.05) \\
\downarrow \text { CRP }(P<0.05) \\
\downarrow \text { IL-6 }(P<0.05) \\
\downarrow \text { Plasma ROS }(P<0.05)\end{array}$ & 144 \\
\hline $\begin{array}{l}\text { Stage III NSCLC patients }(n 40) \\
\text { Open-label with contemporaneous } \\
\text { control group trial }\end{array}$ & $\begin{array}{l}\text { Two cycles of: CBCDA/VNB (twenty- } \\
\text { eight patients); CBCDA/GCB (four } \\
\text { patients); CIS with VNB or VP-16 } \\
\text { (eight patients) }\end{array}$ & Oral FO (2.2 G EPA/D) & $\begin{array}{l}\text { change in muscle between } \\
\text { baseline and the end of } \\
\text { chemotherapy }\end{array}$ & $\begin{array}{l}\uparrow \text { Weight gain }(P=0.05) \\
\uparrow \text { Muscle mass gain }(P=0.01)\end{array}$ & 145 \\
\hline $\begin{array}{l}\text { Stage III NSCLC patients ( } n \text { 46) } \\
\text { Part of a larger open-label trial with } \\
\text { contemporaneous control }\end{array}$ & $\begin{array}{l}\text { Two cycles of palliative } \\
\text { chemotherapy: CBCDA/VNB } \\
\text { (thirty-eight patients); CBCDA/ } \\
\text { GCB (eight patients) }\end{array}$ & Oral FO $(2.5 \mathrm{~g} \mathrm{EPA}+\mathrm{DHA} / \mathrm{d})$ & Chemotherapy response rates & $\begin{array}{l}\uparrow \text { Response rate }(P=0.008) \\
\uparrow 1 \text {-year survival }(P=0.15) \\
\uparrow \text { Clinical benefit }(P=0.02)\end{array}$ & 146 \\
\hline $\begin{array}{l}\text { Stage IV colorectal cancer patients } \\
(n \text { 13) } \\
\text { Prospective, randomised, controlled } \\
\text { open-label pilot study }\end{array}$ & $\begin{array}{l}5-\mathrm{FU}+\mathrm{OXA}+\mathrm{FOL} \text { in eight }(61.5 \%) \\
\text { patients and CAP in five }(38.5 \%) \\
\text { patients }\end{array}$ & $\begin{array}{l}\text { Commercially available formula } \\
\text { enriched in FO (containing } \\
1 \mathrm{~g} \text { EPA), two packs } / \mathrm{d} \text { for a } \\
\text { 12-week period }\end{array}$ & Chemotherapy tolerability & $\begin{array}{l}\uparrow \text { Weight gain }(P=0.045) \\
\uparrow \text { GHS/QoL } \\
\uparrow \text { Chemotherapy tolerability }\end{array}$ & 147 \\
\hline
\end{tabular}

NSCLC, non-small cell lung cancer; CIS, cisplatin; DTX, docetaxel; BV, bevacizumab; REE, resting energy expenditure; GCB, gemcitabine; CRP, C-reactive protein; ROS, reactive oxygen species; CBCDA, carboplatin; VNB, vinorelbine; VP-16, etoposide; FO, fish oil; 5-FU, 5-fluorouracil; OXA, oxaliplatin; FOL, folinic acid; CAP, capecitabine; GHS/QoL, global health status/quality of life. 
Table 12. Human clinical trials: effects of $n-3$ PUFA in combination with conventional antineoplastic drugs

\begin{tabular}{|c|c|c|c|c|c|}
\hline Patients and type of study & Antineoplastic treatment(s) & $n$-3 PUFA treatment & Primary endpoint & Effects & Reference \\
\hline $\begin{array}{l}\text { Patients who underwent surgical } \\
\text { removal of different kinds of } \\
\text { cancers }(n 38) \\
\text { Randomised trial }\end{array}$ & $\begin{array}{l}\text { 5-FU }\left(425 \mathrm{mg} / \mathrm{m}^{2}\right) \text { and LCV } \\
\left(20 \mathrm{mg} / \mathrm{m}^{2}\right) \text { i.v. three times } \\
\text { per week }\end{array}$ & $\begin{array}{c}\text { Oral FO }(2 \mathrm{~g} / \mathrm{d} \text { providing about } \\
0.3 \mathrm{gEPA}+0.4 \mathrm{~g} D \mathrm{DH})\end{array}$ & $\begin{array}{l}\text { Number and function of blood } \\
\text { PMNC }\end{array}$ & $\begin{array}{l}\uparrow \text { PMNC number }(P<0.05) \\
\uparrow \text { PMNC phagocytosis }(P<0.001) \\
\uparrow \text { PMNC } \mathrm{H}_{2} \mathrm{O}_{2} \text { production }(P<0.001) \\
\downarrow \text { Body-weight loss }(P<0.002)\end{array}$ & 148 \\
\hline $\begin{array}{l}\text { Patients with colorectal cancer } \\
(n 11) \\
\text { Randomised, prospective, } \\
\text { controlled clinical trial }\end{array}$ & $\begin{array}{l}\text { CAP, OXA, 5-FU and LCV (dose not } \\
\text { specified) }\end{array}$ & $\begin{array}{l}\text { Oral FO }(2 \mathrm{~g} / \mathrm{d} \text { of fish oil providing } \\
360 \mathrm{mg} \text { EPA/d and } 240 \mathrm{mg} / \mathrm{d} \\
\text { DHA, for } 9 \text { weeks })\end{array}$ & $\begin{array}{l}\text { Inflammation markers, CRP: } \\
\text { albumin ratio, nutritional status } \\
\text { and plasma fatty acid profile }\end{array}$ & $\begin{array}{l}\downarrow \text { Serum CRP levels }(P=0.04) \\
\downarrow \text { Plasma ARA }(P<0.05) \\
\uparrow \text { Plasma EPA and DHA }(P<0.05)\end{array}$ & 149 \\
\hline $\begin{array}{l}\text { Patients with locally advanced } \\
\text { oesophageal squamous cell } \\
\text { carcinoma ( } n 71) \\
\text { Randomised, controlled trial }\end{array}$ & $\begin{array}{l}\text { CCRT (5-FU: } 750 \mathrm{mg} / \mathrm{m}^{2} \text { per d by } \\
\text { continuous i.v. infusion on days } \\
1-4 \text { and days } 29-32+\mathrm{CIS} \text { : } \\
75 \mathrm{mg} / \mathrm{m}^{2} \text { per } \mathrm{d} \text { by rapid i.v. } \\
\text { infusion on day } 1 \text { and day } 29 ; \\
\text { radiation: } 28 \text { fractions of } 1.8 \mathrm{~Gy} \\
\text { each (five fractions/week), starting } \\
\text { on day } 1 \text { concurrent with the } \\
\text { beginning of chemotherapy) }\end{array}$ & $\begin{array}{l}\text { Enteral immunonutrition } \\
\text { containing } n-3 \text { PUFA ( } 20 \% \text { of } \\
\text { total fat: corresponding to about } \\
0.56 \mathrm{~g} n-3 \text { PUFA } 100 \mathrm{ml} \text { ), } \\
\text { glutamine and arginine }\end{array}$ & $\begin{array}{l}\text { Reduction of inflammatory } \\
\text { markers and improvement of } \\
\text { immune function }\end{array}$ & $\begin{array}{l}\text { Serum levels of: } \\
\downarrow \text { CRP }(P=0.001) \\
\downarrow \text { TNF-a }(P=0.014)\end{array}$ & 152 \\
\hline $\begin{array}{l}\text { Breast cancer patients ( } n \text { 25) } \\
\text { Open-label single-arm phase II } \\
\text { study }\end{array}$ & $\begin{array}{l}\left.\text { CYC (i.v. infusion: } 500 \mathrm{mg} / \mathrm{m}^{2}\right), 5-F U \\
\left(500 \mathrm{mg} / \mathrm{m}^{2}\right), \text { followed by EPI (i.v. } \\
\left.\text { infusion: } 75 \mathrm{mg} / \mathrm{m}^{2}\right) \text {, administered } \\
\text { on day } 1 \text { every } 3 \text { weeks }\end{array}$ & $\begin{array}{l}\text { DHASCO oil (providing } 1.8 \mathrm{~g} \mathrm{DHA} / \\
\text { d) starting } 5-10 \mathrm{~d} \text { before } \\
\text { chemotherapy and for all the } \\
\text { duration of chemotherapy } \\
\text { (5 months) }\end{array}$ & Response rate and safety profile & $\begin{array}{l}\uparrow \text { Time to progression }(P=0.02) \\
\uparrow \text { Overall survival }(P=0.07)\end{array}$ & 153 \\
\hline
\end{tabular}

5-FU, 5-fluorouracil; LCV, leucovorin; i.v., intravenous; FO, fish oil; PMNC, polymorphonuclear cells; CAP, capecitabine; OXA, oxaliplatin; CRP, C-reactive protein; ARA, arachidonic acid; CCRT, concurrent chemoradiotherapy; CIS, cisplatin; CYC, cyclophosphamide; EPI, epirubicin. 
Table 13. Human clinical trials: effects of $n-3$ PUFA in combination with conventional antineoplastic drugs

\begin{tabular}{|c|c|c|c|c|c|}
\hline Patients and type of study & Antineoplastic treatment(s) & $n$-3 PUFA treatment & Primary endpoint & Effects & Reference \\
\hline $\begin{array}{l}\text { Breast cancer patients ( } n \text { 57) } \\
\text { Randomised, double-blind, } \\
\text { placebo-controlled trial }\end{array}$ & $\begin{array}{l}\text { PTX }\left(175 \mathrm{mg} / \mathrm{m}^{2} \text { over a } 3 \mathrm{~h} \text { infusion }\right. \\
\text { every } 3 \text { weeks for four cycles) }\end{array}$ & $\begin{array}{l}\text { n-3 Fatty acid soft gelatin capsules } \\
(1920 \mathrm{mg} / \mathrm{d} \text {, providing about } \\
1.2 \mathrm{~g} \mathrm{EPA}+\mathrm{DHA})\end{array}$ & $\begin{array}{l}\text { Prophylaxis against PTX- } \\
\text { induced neurotoxicity }\end{array}$ & $\begin{array}{l}\downarrow \text { Incidence of PTX-induced } \\
\text { neuropathy }(P=0.029)\end{array}$ & 154 \\
\hline $\begin{array}{l}\text { Postmenopausal breast cancer } \\
\text { survivors ( } n 38 \text { ) } \\
\text { Randomised, double-blind, placebo- } \\
\text { controlled, pilot study }\end{array}$ & $\begin{array}{l}\text { Aromatase inhibitors (dose not } \\
\text { specified) }\end{array}$ & $\begin{array}{l}4 \mathrm{~g} \mathrm{EPA}+\mathrm{DHA} / \mathrm{d}(2520 \mathrm{mg} \text { EPA, } \\
1680 \mathrm{mg} \mathrm{DHA})\end{array}$ & $\begin{array}{l}\text { Anti-inflammatory action, } \\
\text { decreased bone turnover }\end{array}$ & $\downarrow$ Bone resorption $(P<0.05)$ & 156 \\
\hline $\begin{array}{l}\text { Patients with advanced pancreatic } \\
\text { cancer }(n 32) \\
\text { Part of a single-arm, phase II trial }\end{array}$ & $\begin{array}{l}\text { GCB }\left(1000 \mathrm{mg} / \mathrm{m}^{3} \text {, weekly for }\right. \\
3 \text { weeks })\end{array}$ & $\begin{array}{l}\text { Intravenous } n-3 \text { fatty acid-rich lipid } \\
\text { emulsion ( } 100 \mathrm{~g} \text {, corresponding } \\
\text { to about } 6 \mathrm{~g} \text { EPA + DHA, weekly } \\
\text { for } 3 \text { weeks) }\end{array}$ & $\begin{array}{l}\text { Link between pro-inflammatory } \\
\text { circulating cytokines and } \\
\text { growth factors and OS and } \\
\text { PFS }\end{array}$ & $\begin{array}{l}\downarrow \text { Plasma PDGF }(P=0.05) \text { and FGF } \\
(P=0.03) \\
\text { Tendency towards improved OS in } \\
\text { PDGF responders } \\
\text { Significantly improved PFS in FGF } \\
\text { responders }\end{array}$ & 158 \\
\hline $\begin{array}{l}\text { Patients with head and neck and } \\
\text { oesophageal cancer }(n 111) \\
\text { Randomised, double-blind, } \\
\text { controlled, multicentre trial }\end{array}$ & $\begin{array}{l}\text { CCRT (CIS/CBCDA or MMC, with or } \\
\text { without 5-FU, and radiation } \\
\text { therapy: } 66 \text { Gy in single fractions } \\
\text { of } 1.8-2.0 \text { Gy daily) }\end{array}$ & $\begin{array}{l}\text { Enteral nutrition ( } 500 \mathrm{ml} \\
\text { containing } 2 \mathrm{~g} \text { of EPA and } 0.85 \mathrm{~g} \\
\text { DHA, via percutaneous } \\
\text { endoscopic gastrostomy) }\end{array}$ & $\begin{array}{l}\text { Change of body cell mass and } \\
\text { nutritional and functional } \\
\text { status }\end{array}$ & $\begin{array}{l}\uparrow \text { Body weight }(P=0.05) \\
\uparrow \text { Nutritional status (Kondrup score) } \\
\quad(P=0.0165)\end{array}$ & 160 \\
\hline $\begin{array}{l}\text { Patients with acute myeloid } \\
\text { leukaemia }(n 13) \\
\text { Phase II trial with a historical control } \\
\text { group }\end{array}$ & $\begin{array}{l}\text { CY } 200 \mathrm{mg} / \mathrm{m}^{2}+\text { IDA } 12 \mathrm{mg} / \mathrm{m}^{2} \text { or } \\
\text { CY } 200 \mathrm{mg} / \mathrm{m}^{2}+\text { DRC } 45 \mathrm{mg} / \mathrm{m}^{2} \\
\text { or CY } 200 \mathrm{mg} / \mathrm{m}^{2}+\text { EP or } \mathrm{CY} \\
200 \mathrm{mg} / \mathrm{m}^{2}+\mathrm{MXT} \text {, and the } \\
\text { addition of BV } 5-10 \mathrm{mg} / \mathrm{kg} \text { ) }\end{array}$ & $\begin{array}{l}\text { Intravenous } n-3 \text { PUFA formulation } \\
\text { (Omegaven }{ }^{\text {TM}} ; 100 \mathrm{ml} / \mathrm{d} \text { ) } \\
\text { containing } 10 \mathrm{~g} \text { FO providing } \\
1.90 \mathrm{~g} \mathrm{DHA} \text { and } 1.94 \mathrm{~g} \text { EPA for } \\
4 \text { weeks }\end{array}$ & $\begin{array}{l}\text { Protection from chemotherapy- } \\
\text { induced severe neutropenic } \\
\text { enterocolitis }\end{array}$ & $\begin{array}{l}\text { Little evidence that } n \text {-3 PUFA addition } \\
\text { reduces neutropenic enterocolitis }\end{array}$ & 161 \\
\hline
\end{tabular}

PTX, paclitaxel; GCB, gemcitabine; OS, overall survival; PFS, progression-free survival; PDGF, platelet-derived growth factor; FGF, fibroblast growth factor; CCRT, concomitant chemotherapy; CIS, cisplatin; CBCDA, carboplatin; MMC, mytomicin C; 5-FU, 5-fluorouracil; CY, cytarabin; IDA, idarubicin; DRC, daunorubicin; EP, etoposide phosphate; MXT, mitoxantron; BV, bevacizumab; FO, fish oil. 
of tumours (mainly gastrointestinal) were also recently reported by Bonatto et $a .^{(148)}$ (Table 12). In this case, the authors analysed neutrophil number and functions and observed that the FO supplementation was able to prevent the chemotherapyinduced decrease in these parameters ${ }^{(148)}$, as well as cachexiainduced body-weight loss. In agreement, a randomised, prospective, controlled clinical trial ${ }^{(149)}$ recently performed demonstrated that the dietary FO supplementation administered to colorectal cancer patients for 9 weeks was able to significantly improve CRP values, CRP/albumin status, and plasma FA profile during chemotherapy. These findings are of interest, since they further support the hypothesis that an increased intake of $n-3$ PUFA may suppress the permanent serum inflammatory status and the high serum levels of inflammatory cytokines observed in cancer patients, and related to cachexia and poor prognosis ${ }^{(150,151)}$. Moreover, whereas the FO patients gained body weight, those receiving only chemotherapy lost it, even though the difference did not reach significance $(P=0 \cdot 72)$. Again, however, this study, even though highly promising, had the main limitation of having enrolled a very small number of patients (only eleven patients). However, a further confirmation of the anti-inflammatory effect of $n-3$ PUFA during chemotherapy came from a larger recent randomised controlled trial (Table 12) performed on patients with oesophageal squamous cell carcinoma treated with chemo- (5-FU and cisplatin) and radiotherapy $^{(152)}$, and supplemented with a combination of $n-3$ FA, glutamine and arginine. Also in this case a significant decrease in the levels of serum CRP and TNF- $\alpha$ was reported in patients receiving enteral nutrition providing PUFA.

$n$-3 PUFA supplementation has also been investigated in breast cancer patients with visceral metastases and treated with an anthracycline-based chemotherapy ${ }^{(153)}$ (Table 12). The trial was one small (twenty-five patients) open-label single-arm phase II study analysing as the primary outcome the efficacy of an oral DHA supplementation. They found that DHA, besides not inducing adverse side effects, increased both the time to progression $(P=0.02)$ and the overall survival $(P=0.007)$ of patients with respect to the control group, and the effects were particularly remarkable in the women showing the highest DHA incorporation into plasma phospholipids. Certainly, as the authors themselves stated, this study also warrants confirmation through a larger placebo-controlled randomised phase III clinical trial stratified on patients' DHA incorporation.

Instead, in another randomised double-blind placebocontrolled trial, breast cancer patients were subjected to paclitaxel-based chemotherapy and supplemented with FO all through the chemotherapy treatment, as well as 1 month after the end of therapy (Table 13). The authors found a significantly decreased incidence of chemotherapy-induced peripheral neuropathy in $n-3$ FA-supplemented patients $(P=0 \cdot 029)^{(154)}$. Even though also this study examined a small sample (fiftyseven patients), this result is very promising since, in spite of the increased survival rate of breast cancer patients due to the recent development of new therapeutic strategies, peripheral neuropathy associated with paclitaxel chemotherapy often impairs patients' quality of life and induces oncologists to change or even to stop the treatment ${ }^{(155)}$. Likewise, another interesting finding was obtained in a recent randomised, double-blind, placebo-controlled pilot study (thirty-eight patients) performed in postmenopausal breast cancer survivors after chemotherapy with aromatase inhibitors. The authors demonstrated that a short-term, high-dose $n$-3 PUFA-rich FO supplementation was able to significantly reduce bone resorption $(P<0.05)^{(156)}$. This effect is interesting since, together with decreased bone mineral density, bone resorption represents an undesired side-effect induced by aromatase inhibitors in breast cancer patients ${ }^{(157)}$.

Also patients with advanced pancreatic cancer were treated with gemcitabine and intravenous (i.v.) n-3-rich Lipidem® emulsion (B Braun, Melsungen) in a single-arm phase II trial (thirty-two patients) ${ }^{(158)}$.The authors observed that the serum concentrations of platelet-derived growth factor and fibroblast growth factor decreased significantly with treatment over time. This finding, in spite of the small number of patients examined, is of note since increased serum concentrations of these proangiogenic factors have been correlated with the development of most human solid tumours ${ }^{(159)}$. Moreover, these changes were associated with an improved overall survival and a significantly higher progression-free survival. Positive results were also obtained in a recent and larger multicentre study (Table 13), performed on head and neck and oesophageal cancer patients $(111 \text { patients })^{(160)}$. They were treated with enteral $n$-3 nutrition and concurrent chemo-radiotherapy, and a significant improvement in the nutritional status (evaluated as Kondrup score; $P=0.0165$ ) was observed (Table 13).

Conversely, significant differences were not found between the control and $n-3$ groups in one pilot phase II trial recently performed to investigate the protective effect that an i.v. supplementation of $n$-3 PUFA may exert in reducing the incidence and severity of enterocolitis developing in thirteen patients with acute myeloid leukaemia or at high risk of myelodysplastic syndrome undergoing myeloablative chemotherapy ${ }^{(161)}$ (Table 13). In this case, an inverse probability of treatment-weighted comparison with a historical control group of consecutive AML patients was performed. The authors found that the $\mathrm{CI}$ of incidence rate ratios of serious adverse events comparing experimental and control were wide. Therefore, they were not able to exclude a clinically relevant increase or decrease in the rate of serious adverse events. However, the authors themselves suggested that more adequately designed randomised trials of moderate to large size could better determine whether the intervention with $n-3$ PUFA may be beneficial.

Certainly, from the analysis of all the trials performed so far, it is impressive to notice how the methods used to enrich cells and tissues of cancer patients with $n$-3 PUFA (in the form of dietary supplements, i.v. inoculation or enteral nutrition) are absolutely heterogeneous, making the comparison between the outcomes very complicated. Moreover, most of the studies are small and for this reason await confirmation by future larger studies. However, in spite of these limitations, and although the number of these human clinical trials remains quite scarce, most of the results analysed strongly suggest multiple advantages deriving from adding $n$-3 PUFA to anticancer therapies. In particular, some of these results suggest that this therapeutic approach could be extremely useful in order to: (a) reduce weight loss and cachexia in cancer patients receiving chemotherapy ${ }^{(143-145,147,148,160)}$; 
(b) decrease inflammation related to either the cancer condition or the antineoplastic therapy ${ }^{(143,144,149,152)}$; (c) enhance the tolerability of highly cytotoxic chemotherapeutic drugs ${ }^{(147,148,154,156)}$; and (d) improve the efficiency of the antineoplastic treatments ${ }^{(146,153,158)}$

\section{DHA-paclitaxel conjugate studies}

Finally, we cannot omit from our analysis another therapeutic approach used in some clinical trials, which involves the use of DHA-paclitaxel, a conjugate molecule synthesised by covalently linking DHA to the chemotherapeutic drug paclitaxel. One of these studies ${ }^{(162)}$ was a phase I trial that examined the toxicity and pharmacokinetics of DHA-paclitaxel in patients bearing different kinds of advanced refractory solid tumours. The patients were treated with DHA-paclitaxel as a $2 \mathrm{~h}$ i.v. infusion every 3 weeks at doses ranging from 200 to $1100 \mathrm{mg} / \mathrm{m}^{2}$. It was demonstrated that DHA-paclitaxel was able to strongly increase the pharmacokinetics of paclitaxel alone at the dose of $175 \mathrm{mg} / \mathrm{m}^{2}$. Moreover, the authors found that the DHA-paclitaxel conjugate was less cytotoxic in terms of neutropenia, alopecia and peripheral neuropathy. Similarly, another phase I clinical trial ${ }^{(163)}$ demonstrated that DHA-paclitaxel administered weekly to a maximum dose of $600 \mathrm{mg} / \mathrm{m}^{2}$ was well tolerated, and that a weekly continuous infusion was more active than a treatment performed with the taxane alone every 3 weeks or weekly. A prospective, open-label, non-randomised, multi-institutional phase II study ${ }^{(164)}$ was also performed to assess the anti-tumour activity and safety of DHA-paclitaxel (900 and $1100 \mathrm{mg} / \mathrm{m}^{2}$, as i.v. infusion every 3 weeks) as first-line treatment of patients with advanced NSCLC. However, in this case DHApaclitaxel administered as a single-agent showed little activity in patients with advanced NSCLC, with about $40 \%$ patients achieving either stable disease or a partial response after treatment. A phase II open-label study ${ }^{(165)}$ was also performed using DHA-paclitaxel administered at the dose of $1100 \mathrm{mg} / \mathrm{m}^{2}$ by i.v. infusion every $21 \mathrm{~d}$ in patients with locally advanced or metastatic adenocarcinoma of the oesophagus, oesophago-gastric junction or stomach, which had not been previously treated. However, the results demonstrated that the DHA-paclitaxel treatment induced only a partial response $(9.4 \%)$, and that the haematological toxicity was comparable with that induced by paclitaxel alone (neutropenia in $93 \%$ of patients). Three similar clinical studies ${ }^{(166-168)}$ were also conducted in melanoma patients. In particular, Homsi et al. ${ }^{(166)}$ administered DHA-paclitaxel $\left(900 \mathrm{mg} / \mathrm{m}^{2}\right)$ or dacarbazine $\left(1000 \mathrm{mg} / \mathrm{m}^{2}\right)$ every 3 weeks in metastatic melanoma patients not treated before, and found that its efficacy was not higher than that of dacarbazine, even though DHA-paclitaxel was well tolerated. Similarly, Bedikian et $a l^{(167)}$, in a phase III study in patients bearing a metastatic malignant melanoma and treated with DHA-paclitaxel or dacarbazine, did not find any difference in the patient survival and response rate between the two treatments. Actually, the authors found higher myelosuppression in patients receiving DHA-paclitaxel. Finally, a phase II open-label study ${ }^{(168)}$ was conducted by treating patients with metastatic uveal melanoma (previously treated or not with standard chemotherapy) with DHA-paclitaxel at the dose of $500 \mathrm{mg} / \mathrm{m}^{2}$ per week for 5 consecutive weeks. As a single-agent therapy, DHA-paclitaxel was found to be safe and well tolerated, but its efficacy was observed only in $32 \%$ of patients achieving stable disease. In conclusion, the outcomes of the clinical studies performed with the DHA-paclitaxel conjugate appear controversial with respect to both the preclinical studies and the few clinical studies in which $n$-3 PUFA were given in combination with other chemotherapeutic agents or with paclitaxel itself ${ }^{(154)}$, but not as a DHA conjugate. It should be noticed, however, that the reason for covalently binding DHA to paclitaxel in the conjugate was not for taking advantage of the antineoplastic properties of DHA, but just for enhancing the cellular uptake of paclitaxel, thanks to the lipid carrier function of DHA, and for making slower the paclitaxel release inside the cells. For this reason, in the trials performed with the DHA-paclitaxel conjugate, the treatment scheme was quite unusual for a nutritional compound such as DHA. As a matter of fact, in these studies DHA was always administered at concentrations much lower and at intervals between administrations much longer than those shown to be effective in the other clinical trials where $n-3$ PUFA supplementations were combined to concomitant, but separate, treatments with a variety of antineoplastic agents.

\section{Conclusions}

Overall, all the data analysed here concur to support the hypothesis that $n$ - 3 PUFA used in combination with various conventional antineoplastic agents may exert beneficial effects, either by increasing the efficacy of the concomitant therapies, and/or by reducing their deleterious side-effects. The potentiating action of $n-3$ PUFA has been widely demonstrated both in in vitro and animal studies, thus attracting considerable interest. Several human studies have recently confirmed their ability to sensitise cancer cells to the action of chemical and radiation therapy, even though their number appears still too small to draw definitive conclusions. Moreover, the number of patients enrolled in the clinical trials is often too limited. This highlights the need to undertake further studies evaluating potential molecular targets for each type of cancer and anticancer agent studied in combination with $n$-3 PUFA. Finally, it could also be hypothesised a therapy combining these FA, which is safe, quite inexpensive, and provided with pleiotropic effects and multi-targeted action at molecular levels, with the innovative single-targeted cancer therapies, which, instead, are very expensive and, as recently observed, not completely devoid of dangerous side-effects ${ }^{(169,170)}$.

\section{Acknowledgements}

The present review was supported in part by grants D.1 2013 and D.1 2014, and D.3.2 2013 to G. C. from 'Università Cattolica del S. Cuore', Rome, Italy, within its programme of promotion and diffusion of scientific research.

\section{References}

1. Cicero AF, Reggi A, Parini A, et al. (2012) Application of polyunsaturated fatty acids in internal medicine: beyond the established cardiovascular effects. Arch Med Sci 8, 784-793. 
2. Wendel M \& Heller AR (2009) Anticancer actions of omega-3 fatty acids: current state and future perspectives. Anticancer Agents Med Chem 9, 457-470.

3. Deckelbaum RJ \& Torrejon C (2012) The omega-3 fatty acid nutritional landscape: health benefits and sources. $J$ Nutr 142, 587S-591S.

4. Anti M, Marra G, Armelao F, et al. (1992) Effect of omega-3 fatty acids on rectal mucosal cell proliferation in subjects at risk for colon cancer. Gastroenterology 103, 883-891.

5. Anti M, Armelao F, Marra G, et al. (1994) Effects of different doses of fish oil on rectal cell proliferation in patients with sporadic colonic adenomas. Gastroenterology 107, 1709-1718.

6. Palozza P, Anti M, Franceschelli P, et al. (1995) Modulation of vitamin $\mathrm{E}$ level as a possible mechanism of the antiproliferative effect of $n-3$ PUFA. In Oxygen Paradox, pp. 653-664 [KJA Davies and F Ursini, editors]. Padova: CLEUP University Press.

7. Calviello G, Palozza P, Piccioni E, et al. (1998) Dietary supplementation with eicosapentaenoic and docosahexaenoic acid inhibits growth of Morris hepatocarcinoma 3924A in rats: effects on proliferation and apoptosis. Int J Cancer 75, 699-705.

8. Calviello G, Palozza P, Franceschelli P, et al. (1999) Eicosapentaenoic acid inhibits the growth of liver preneoplastic lesions and alters membrane phospholipid composition and peroxisomal $\beta$-oxidation. Nutr Cancer 34, 206-212.

9. Calviello G, Palozza P, Di Nicuolo F, et al. (2000) n-3 PUFA dietary supplementation inhibits proliferation and storeoperated calcium influx in thymoma cells growing in Balb/c mice. J Lipid Res 41, 182-189.

10. Vecchini A, Ceccarelli V, Susta F, et al. (2004) Dietary $\alpha$-linolenic acid reduces COX-2 expression and induces apoptosis of hepatoma cells. J Lipid Res 45, 308-316.

11. Calviello G, Di Nicuolo F, Gragnoli S, et al. (2004) n-3 PUFAs reduce VEGF expression in human colon cancer cells modulating the COX-2/PGE 2 induced ERK-1 and -2 and HIF-1 $\alpha$ induction pathway. Carcinogenesis 25, 2303-2310.

12. Calviello G, Di Nicuolo F, Serini S, et al. (2005) Docosahexaenoic acid enhances the susceptibility of human colorectal cancer cells to 5-fluorouracil. Cancer Chemother Pharmacol 55, 12-20.

13. Calviello G, Resci F, Serini S, et al. (2007) Docosahexaenoic acid induces proteasome-dependent degradation of $\beta$-catenin, down-regulation of survivin and apoptosis in human colorectal cancer cells not expressing COX-2. Carcinogenesis 28, 1202-1209.

14. Serini S, Trombino S, Oliva F, et al. (2008) Docosahexaenoic acid induces apoptosis in lung cancer cells by increasing MKP-1 and down-regulating p-ERK1/2 and p-p38 expression. Apoptosis 13, 1172-1183.

15. Serini S, Fasano E, Piccioni E, et al. (2012) DHA induces apoptosis and differentiation in human melanoma cells in vitro: involvement of HuR-mediated COX-2 mRNA stabilization and $\beta$-catenin nuclear translocation. Carcinogenesis 33, 164-173.

16. Fasano E, Serini S, Piccioni E, et al. (2012) DHA induces apoptosis by altering the expression and cellular location of GRP78 in colon cancer cell lines. Biochim Biophys Acta 1822, 1762-1772.

17. Calviello G, Serini S \& Piccioni E (2007) n-3 Polyunsaturated fatty acids and the prevention of colorectal cancer: molecular mechanisms involved. Curr Med Chem 14, 3059-3069.

18. Serini S, Piccioni E, Merendino N, et al. (2009) Dietary polyunsaturated fatty acids as inducers of apoptosis: implications for cancer. Apoptosis 14, 135-152.
19. Hu Y, Sun H, Owens RT, et al. (2010) Syndecan-1dependent suppression of PDK1/Akt/Bad signaling by docosahexaenoic acid induces apoptosis in prostate cancer. Neoplasia 12, 826-836.

20. Notarnicola M, Messa C, Refolo MG, et al. (2011) Polyunsaturated fatty acids reduce fatty acid synthase and hydroxy-methyl-glutaryl CoA-reductase gene expression and promote apoptosis in HepG2 cell line. Lipids Health Dis 10, 10.

21. Sun H, Hu Y, Gu Z, et al. (2011) Omega-3 fatty acids induce apoptosis in human breast cancer cells and mouse mammary tissue through syndecan- 1 inhibition of the MEKErk pathway. Carcinogenesis 32, 1518-1524.

22. Ma DW, Seo J, Switzer KC, et al. (2004) n-3 PUFA and membrane microdomains: a new frontier in bioactive lipid research. J Nutr Biochem 15, 700-706.

23. Hardman WE (2002) Omega-3 fatty acids to augment cancer therapy. J Nutr 132, Suppl. 11, 3508S-3512S.

24. Serhan CN (2005) Novel eicosanoid and docosanoid mediators: resolvins, docosatrienes, and neuroprotectins. Curr Opin Clin Nutr Metab Care 8, 115-121.

25. Serhan CN, Clish CB, Brannon J, et al. (2000) Novel functional sets of lipid-derived mediators with antiinflammatory actions generated from omega- 3 fatty acids via cyclooxygenase 2-nonsteroidal antiinflammatory drugs and transcellular processing. J Exp Med 192, 1197-1204.

26. Marcheselli VL, Hong S, Lukiw WJ, et al. (2003) Novel docosanoids inhibit brain ischemia-reperfusion-mediated leukocyte infiltration and pro-inflammatory gene expression. J Biol Chem 278, 43807-43817.

27. Mukherjee PK, Marcheselli VL, Serhan CN, et al. (2004) Neuroprotectin D1: a docosahexaenoic acid-derived docosatriene protects human retinal pigment epithelial cells from oxidative stress. Proc Natl Acad Sci U S A 101, 8491-8496.

28. Gonda TA, Tu S \& Wang TC (2009) Chronic inflammation, the tumor microenvironment and carcinogenesis. Cell Cycle 8, 2005-2013.

29. Serini S, Fasano E, Piccioni E, et al. (2011) Dietary $n$-3 polyunsaturated fatty acids and the paradox of their health benefits and potential harmful effects. Chem Res Toxicol 24, 2093-2105.

30. Mazière C, Conte MA, Degonville J, et al. (1999) Cellular enrichment with polyunsaturated fatty acids induces an oxidative stress and activates the transcription factors AP1 and NFкB. Biochem Biophys Res Commun 265, 116-122.

31. Ding WQ, Vaught JL, Yamauchi H, et al. (2004) Differential sensitivity of cancer cells to docosahexaenoic acid-induced cytotoxicity: the potential importance of down-regulation of superoxide dismutase 1 expression. Mol Cancer Ther 3, 1109-1117.

32. Colquhoun A \& Schumacher RI (2001) $\gamma$-Linolenic acid and eicosapentaenoic acid induce modifications in mitochondrial metabolism, reactive oxygen species generation, lipid peroxidation and apoptosis in Walker 256 rat carcinosarcoma cells. Biochim Biophys Acta 1533, 207-219.

33. Germain E, Lavandier F, Chajès V, et al. (1999) Dietary $n$-3 polyunsaturated fatty acids and oxidants increase rat mammary tumor sensitivity to epirubicin without change in cardiac toxicity. Lipids 34, Suppl. 1, S203.

34. Gleissman H, Yang R, Martinod K, et al. (2010) Docosahexaenoic acid metabolome in neural tumors: identification of cytotoxic intermediates. FASEB J 24, 906-915.

35. Calviello G, Serini S \& Palozza P (2006) n-3 Polyunsaturated fatty acids as signal transduction modulators and therapeutical agents in cancer. Curr Signal Transd Ther 1, $255-271$ 
36. Calviello G, Su HM, Weylandt KH, et al. (2013) Experimental evidence of $\omega-3$ polyunsaturated fatty acid modulation of inflammatory cytokines and bioactive lipid mediators: their potential role in inflammatory, neurodegenerative, and neoplastic diseases. Biomed Res Int 2013, 743171.

37. Calviello G, Serini S, Piccioni E, et al. (2009) Antineoplastic effects of $n-3$ polyunsaturated fatty acids in combination with drugs and radiotherapy: preventive and therapeutic strategies. Nutr Cancer 61, 287-301.

38. Song F, Parekh S, Hooper L, et al. (2010) Dissemination and publication of research findings: an updated review of related biases. Health Technol Assess 14, 1-193.

39. Granci V, Cai F, Lecumberri E, et al. (2013) Colon cancer cell chemosensitisation by fish oil emulsion involves apoptotic mitochondria pathway. Br J Nutr 109, 1188-1195.

40. Jordan A \& Stein J (2003) Effect of an omega-3 fatty acid containing lipid emulsion alone and in combination with 5-fluorouracil (5-FU) on growth of the colon cancer cell line Caco-2. Eur J Nutr 42, 324-331.

41. De Carlo F, Witte TR, Hardman WE, et al. (2013) Omega-3 eicosapentaenoic acid decreases CD133 colon cancer stem-like cell marker expression while increasing sensitivity to chemotherapy. PLOS ONE 8, e69760.

42. Presnell SC, Petersen B \& Heidaran M (2002) Stem cells in adult tissues. Semin Cell Dev Biol 13, 369-376.

43. Reya T, Morrison SJ, Clarke MF, et al. (2001) Stem cells, cancer, and cancer stem cells. Nature 414, 105-111.

44. Vasudevan A, Yu Y, Banerjee S, et al. (2014) Omega-3 fatty acid is a potential preventive agent for recurrent colon cancer. Cancer Prev Res (Phila) 7, 1138-1148.

45. El-Bayoumy K, Rao CV \& Reddy BS (2001) Multiorgan sensitivity to anticarcinogenesis by the organoselenium 1,4-phenylenebis(methylene)selenocyanate. Nutr Cancer 40, 18-27.

46. Narayanan BA, Narayanan NK, Desai D, et al. (2004) Effects of a combination of docosahexaenoic acid and 1,4 -phenylene bis(methylene) selenocyanate on cyclooxygenase 2 , inducible nitric oxide synthase and $\beta$-catenin pathways in colon cancer cells. Carcinogenesis 25, 2443-2449.

47. Vaculová A, Hofmanová J, Andera L, et al. (2005) TRAIL and docosahexaenoic acid cooperate to induce HT-29 colon cancer cell death. Cancer Lett 229, 43-48.

48. Skender B, Hofmanová J, Slavík J, et al. (2014) DHAmediated enhancement of TRAIL-induced apoptosis in colon cancer cells is associated with engagement of mitochondria and specific alterations in sphingolipid metabolism. Biochim Biophys Acta 1841, 1308-1317.

49. Nagane M, Huang HJ \& Cavenee WK (2001) The potential of TRAIL for cancer chemotherapy. Apoptosis 6, 191-197.

50. Zhang XD, Nguyen T, Thomas WD, et al. (2000) Mechanisms of resistance of normal cells to TRAIL induced apoptosis vary between different cell types. Fed Eur Biochem Soc Lett 482, 193-199.

51. Refaat A, Abd-Rabou A \& Reda A (2014) TRAIL combinations: the new 'trail' for cancer therapy. Oncol Lett 7, 13271332.

52. Ravi R \& Bedi A (2002) Requirement of $B A X$ for TRAIL/ Apo2L-induced apoptosis of colorectal cancers: synergism with sulindac-mediated inhibition of $\mathrm{Bcl}-\mathrm{x}_{\mathrm{L}}$. Cancer Res $\mathbf{6 2}$ $1583-1587$.

53. Gillissen B, Wendt J, Richter A, et al. (2010) Endogenous Bak inhibitors $\mathrm{Mcl}-1$ and $\mathrm{Bcl}-\mathrm{x}_{\mathrm{L}}$ : differential impact on TRAIL resistance in Bax-deficient carcinoma. J Cell Biol 188, 851-862.

54. Kello M, Mikes J, Jendzelovský R, et al. (2010) PUFAs enhance oxidative stress and apoptosis in tumour cells exposed to hypericin-mediated PDT. Photochem Photobiol Sci 9, 1244-1251.

55. Kumamoto-Yonezawa Y, Sasaki R, Suzuki Y, et al. (2010) Enhancement of human cancer cell radiosensitivity by conjugated eicosapentaenoic acid: a mammalian DNA polymerase inhibitor. Int J Oncol 36, 577-584.

56. Cai F, Sorg O, Granci V, et al. (2014) Interaction of $\omega-3$ polyunsaturated fatty acids with radiation therapy in two different colorectal cancer cell lines. Clin Nutr 33, 164-170.

57. Manda K, Kriesen S, Hildebrandt G, et al. (2011) Omega-3 fatty acid supplementation in cancer therapy: does eicosapentanoic acid influence the radiosensitivity of tumor cells? Strablenther Onkol 187, 127-134.

58. Lim SJ, Lee E, Lee EH, et al. (2012) Docosahexaenoic acid sensitizes colon cancer cells to sulindac sulfide-induced apoptosis. Oncol Rep 27, 2023-2030.

59. Shi J, He Q, An J, et al. (2009) Sulindac sulfide differentially induces apoptosis in Smac-proficient and -deficient human colon cancer cells. Mol Cell Pharmacol 1, 92-97.

60. Kuan CY, Walker TH, Luo PG, et al. (2011) Long-chain polyunsaturated fatty acids promote paclitaxel cytotoxicity via inhibition of the MDR1 gene in the human colon cancer Caco-2 cell line. J Am Coll Nutr 30, 265-273.

61. Ullah MF (2008) Cancer multidrug resistance (MDR): a major impediment to effective chemotherapy. Asian Pac J Cancer Prev 9, 1-6.

62. Szakács G, Paterson JK, Ludwig JA, et al. (2006) Targeting multidrug resistance in cancer. Nat Rev Drug Discov 5, 219-234.

63. Bacso Z, Nagy H, Goda K, et al. (2004) Raft and cytoskeleton associations of an ABC transporter: P-glycoprotein. Cytometry A 61, 105-116.

64. Storch CH, Ehehalt R, Haefeli WE, et al. (2007) Localization of the human breast cancer resistance protein (BCRP/ ABCG2) in lipid rafts/caveolae and modulation of its activity by cholesterol in vitro. J Pharmacol Exp Ther 323, 257-264.

65. Klappe K, Hinrichs JW, Kroesen BJ, et al. (2004) MRP1 and glucosylceramide are co-ordinately over expressed and enriched in rafts during multidrug resistance acquisition in colon cancer cells. Int J Cancer 110, 511-522.

66. Gelsomino G, Corsetto PA, Campia I, et al. (2013) Omega 3 fatty acids chemosensitize multidrug resistant colon cancer cells by down-regulating cholesterol synthesis and altering detergent resistant membranes composition. Mol Cancer $12,137$.

67. Germain E, Chajès V, Cognault $\mathrm{S}$, et al. (1998) Enhancement of doxorubicin cytotoxicity by polyunsaturated fatty acids in the human breast tumor cell line MDA-MB-231: relationship to lipid peroxidation. Int J Cancer $\mathbf{7 5}, 578-583$.

68. Mahéo K, Vibet S, Steghens JP, et al. (2005) Differential sensitization of cancer cells to doxorubicin by DHA: a role for lipoperoxidation. Free Radic Biol Med 39, 742-751.

69. Vibet S, Goupille C, Bougnoux P, et al. (2008) Sensitization by docosahexaenoic acid (DHA) of breast cancer cells to anthracyclines through loss of glutathione peroxidase (GPx1) response. Free Radic Biol Med 44, 1483-1491.

70. Menendez JA, Lupu R \& Colomer R (2005) Exogenous supplementation with $\omega$-3 polyunsaturated fatty acid docosahexaenoic acid (DHA; 22:6n-3) synergistically enhances taxane cytotoxicity and downregulates Her-2/neu (c-erbB-2) oncogene expression in human breast cancer cells. Eur J Cancer Prev 14, 263-270.

71. Ewaschuk JB, Newell M \& Field CJ (2012) Docosahexanoic acid improves chemotherapy efficacy by inducing CD95 translocation to lipid rafts in $\mathrm{ER}^{-}$breast cancer cells. Lipids 47, 1019-1030. 
72. Meshkini A \& Yazdanparast R (2012) Involvement of oxidative stress in taxol-induced apoptosis in chronic myelogenous leukemia K562 cells. Exp Toxicol Pathol 64, 357-365.

73. Wirtitsch M, Roth E, Bachleitner-Hofmann T, et al. (2009) Omega-3 and omega-6 polyunsaturated fatty acids enhance arsenic trioxide efficacy in arsenic trioxide-resistant leukemic and solid tumor cells. Oncol Res 18, 83-94.

74. Siddiqui RA, Zerouga M, Wu M, et al. (2005) Anticancer properties of propofol-docosahexaenoate and propofoleicosapentaenoate on breast cancer cells. Breast Cancer Res 7, R645-R654.

75. Mammoto T, Mukai M, Mammoto A, et al. (2002) Intravenous anesthetic, propofol inhibits invasion of cancer cells. Cancer Lett 184, 165-170.

76. Tsuchiya M, Asada A, Arita K, et al. (2002) Induction and mechanism of apoptotic cell death by propofol in HL-60 cells. Acta Anaesthesiol Scand 46, 1068-1074.

77. Siddiqui RA, Harvey KA, Xu Z, et al. (2014) Characterization of lovastatin-docosahexaenoate anticancer properties against breast cancer cells. Bioorg Med Chem 22, 1899-1908.

78. Goldstein JL \& Brown MS (1990) Regulation of the mevalonate pathway. Nature 343, 425-430.

79. Kusama T, Mukai M, Iwasaki T, et al. (2001) Inhibition of epidermal growth factor-induced RhoA translocation and invasion of human pancreatic cancer cells by 3-hydroxy-3methylglutaryl-coenzyme A reductase inhibitors. Cancer Res 61, 4885-4891.

80. Dimitroulakos J, Ye LY, Benzaquen M, et al. (2001) Differential sensitivity of various pediatric cancers and squamous cell carcinomas to lovastatin-induced apoptosis: therapeutic implications. Clin Cancer Res 7, 158-167.

81. Collisson EA, Kleer C, Wu M, et al. (2003) Atorvastatin prevents RhoC isoprenylation, invasion, and metastasis in human melanoma cells. Mol Cancer Ther 2, 941-948.

82. Wei N, Mi MT \& Zhou Y (2007) Influences of lovastatin on membrane ion flow and intracellular signaling in breast cancer cells. Cell Mol Biol Lett 12, 1-15.

83. Kang S, Kim ES \& Moon A (2009) Simvastatin and lovastatin inhibit breast cell invasion induced by H-Ras. Oncol Rep 21, $1317-1322$.

84. Klawitter J, Shokati T \& Moll V (2010) Effects of lovastatin on breast cancer cells: a proteo-metabonomic study. Breast Cancer Res 12, R16.

85. Narayanan NK, Narayanan BA \& Reddy BS (2005) A combination of docosahexaenoic acid and celecoxib prevents prostate cancer cell growth in vitro and is associated with modulation of nuclear factor- $\mathrm{kB}$, and steroid hormone receptors. Int J Oncol 26, 785-792.

86. Narayanan NK, Narayanan BA, Bosland M, et al. (2006) Docosahexaenoic acid in combination with celecoxib modulates HSP70 and $\mathrm{p} 53$ proteins in prostate cancer cells. Int J Cancer 119, 1586-1598.

87. Wang MH, Grossmann ME \& Young CY (2004) Forced expression of heatshock protein 70 increases the secretion of Hsp70 and provides protection against tumour growth. $\mathrm{Br} \mathrm{J}$ Cancer 90, 926-931.

88. Lipinski KS, Pelech S, Mountain A, et al. (2006) Nitroreductasebased therapy of prostate cancer, enhanced by raising expression of heat shock protein 70 , acts through increased anti-tumour immunity. Cancer Immunol Immunother 55, 347-354.

89. Shaikh IA, Brown I, Schofield AC, et al. (2008) Docosahexaenoic acid enhances the efficacy of docetaxel in prostate cancer cells by modulation of apoptosis: the role of genes associated with the NF-кB pathway. Prostate 68, 1635-1646.
90. Petrylak DP (2006) The treatment of hormone-refractory prostate cancer: docetaxel and beyond. Rev Urol 8, S48-S55.

91. Collins R, Trowman R, Norman G, et al. (2006) A systematic review of the effectiveness of docetaxel and mitoxantrone for the treatment of metastatic hormone-refractory prostate cancer. Br J Cancer 95, 457-462.

92. Yared JA \& Tkaczuk KH (2012) Update on taxane development: new analogs and new formulations. Drug Des Devel Ther 6, 371-384.

93. Sturlan S, Baumgartner M, Roth E, et al. (2003) Docosahexaenoic acid enhances arsenic trioxide-mediated apoptosis in arsenic trioxide-resistant HL-60 cells. Blood 101, 4990-4997.

94. Chou WC \& Dang CV (2005) Acute promyelocytic leukemia: recent advances in therapy and molecular basis of response to arsenic therapies. Curr Opin Hematol 12, 1-6.

95. Brown M, Bellon M \& Nicot C (2007) Emodin and DHA potently increase arsenic trioxide interferon- $\alpha$-induced cell death of HTLV-I-transformed cells by generation of reactive oxygen species and inhibition of Akt and AP-1. Blood 109, $1653-1659$

96. Guffy MM, North JA \& Burns CP (1984) Effect of cellular fatty acid alteration on adriamycin sensitivity in cultured L1210 murine leukemia cells. Cancer Res 44, 1863-1866.

97. Zerouga M, Stillwell W \& Jenski LJ (2002) Synthesis of a novel phosphatidylcholine conjugated to docosahexaenoic acid and methotrexate that inhibits cell proliferation. Anticancer Drugs 13, 301-311.

98. de Lima TM, Amarante-Mendes GP \& Curi R (2007) Docosahexaenoic acid enhances the toxic effect of imatinib on Bcr-Abl expressing HL-60 cells. Toxicol In Vitro 21, 1678-1685.

99. Kinsella JE \& Black JM (1993) Effects of polyunsaturated fatty acids on the efficacy of antineoplastic agents toward L5178Y lymphoma cells. Biochem Pharmacol 45, 1881-1887.

100. Fahrmann JF \& Hardman WE (2013) Omega 3 fatty acids increase the chemo-sensitivity of B-CLL-derived cell lines EHEB and MEC-2 and of B-PLL-derived cell line JVM-2 to anti-cancer drugs doxorubicin, vincristine and fludarabine. Lipids Health Dis 12, 36.

101. Cui ZG, Piao JL, Kondo T, et al. (2014) Molecular mechanisms of hyperthermia-induced apoptosis enhanced by docosahexaenoic acid: implication for cancer therapy. Chem Biol Interact 215, 46-53.

102. Overgaard J (1989) The current and potential role of hyperthermia in radiotherapy. Int J Radiat Oncol Biol Phys 16, 535-549.

103. Abdi J, Garssen J, Faber J, et al. (2014) Omega-3 fatty acids, EPA and DHA induce apoptosis and enhance drug sensitivity in multiple myeloma cells but not in normal peripheral mononuclear cells. J Nutr Biochem 25, 1254-1262.

104. Markovina S, Callander NS, O'Connor SL, et al. (2008) Bortezomib-resistant nuclear factor- $\kappa \mathrm{B}$ activity in multiple myeloma cells. Mol Cancer Res 6, 1356-1364.

105. Ri M, Iida S, Nakashima T, et al. (2010) Bortezomib-resistant myeloma cell lines: a role for mutated PSMB5 in preventing the accumulation of unfolded proteins and fatal ER stress. Leukemia 24, 1506-1512.

106. Hideshima T, Chauhan D, Richardson P, et al. (2002) NF-кB as a therapeutic target in multiple myeloma. $J$ Biol Chem 277, 16639-16647.

107. Patterson WL 3rd \& Georgel PT (2014) Breaking the cycle: the role of omega-3 polyunsaturated fatty acids in inflammation-driven cancers. Biochem Cell Biol 92, 321-328.

108. Ikushima S, Fujiwara F, Todo S, et al. (1991) Effects of polyunsaturated fatty acids on vincristine-resistance in human neuroblastoma cells. Anticancer Res 11, 1215-1220. 
109. Lindskog M, Gleissman H, Ponthan F, et al. (2006) Neuroblastoma cell death in response to docosahexaenoic acid: sensitization to chemotherapy and arsenic-induced oxidative stress. Int J Cancer 118, 2584-2593.

110. Rudra PK \& Krokan HE (2001) Cell-specific enhancement of doxorubicin toxicity in human tumour cells by docosahexaenoic acid. Anticancer Res 21, 29-38.

111. Wang F, Bhat K, Doucette M, et al. (2011) Docosahexaenoic acid (DHA) sensitizes brain tumor cells to etoposide-induced apoptosis. Curr Mol Med 11, 503-511.

112. Manda K, Kriesen S, Hildebrandt G, et al. (2011) Omega-3 fatty acid supplementation in cancer therapy: does eicosapentanoic acid influence the radiosensitivity of tumor cells? Strablenther Onkol 187, 127-134.

113. Chiu LC, Tong KF \& Ooi VE (2005) Cytostatic and cytotoxic effects of cyclooxygenase inhibitors and their synergy with docosahexaenoic acid on the growth of human skin melanoma A-375 cells. Biomed Pharmacother 59, S293-S297.

114. Zhuo Z, Zhang L, Mu Q, et al. (2009) The effect of combination treatment with docosahexaenoic acid and 5-fluorouracil on the mRNA expression of apoptosis-related genes, including the novel gene BCL2L12, in gastric cancer cells. In Vitro Cell Dev Biol Anim 45, 69-74.

115. Hardman WE, Barnes CJ, Knight CW, et al. (1997) Effects of iron supplementation and ET-18-OCH3 on MDA-MB 231 breast carcinomas in nude mice consuming a fish oil diet. Br J Cancer 76, 347-354.

116. Hardman WE, Avula CP, Fernandes G, et al. (2001) Three percent dietary fish oil concentrate increased efficacy of doxorubicin against MDA-MB 231 breast cancer xenografts. Clin Cancer Res 7, 2041-2049.

117. Shao Y, Pardini L \& Pardini RS (1995) Dietary menhaden oil enhances mitomycin $\mathrm{C}$ antitumor activity toward human mammary carcinoma MX-1. Lipids 30, 1035-1045.

118. Hardman WE, Moyer MP \& Cameron IL (1999) Fish oil supplementation enhanced CPT-11 (Irinotecan) efficacy against MCF7 breast carcinoma xenografts and ameliorated intestinal side effects. Br J Cancer 81, 440-448.

119. Huan M, Cui H, Teng Z, et al. (2012) In vivo anti-tumor activity of a new doxorubicin conjugate via $\alpha$-linolenic acid. Biosci Biotechnol Biochem 76, 1577-1579.

120. Shao Y, Pardini L \& Pardini RS (1997) Intervention of transplantable human mammary carcinoma MX-1 chemotherapy with dietary menhaden oil in athymic mice: increased therapeutic effects and decreased toxicity of cyclophosphamide. Nutr Cancer 28, 63-73.

121. Hardman WE, Moyer MP \& Cameron IL (2002) Consumption of an omega-3 fatty acids product, INCELL AAFA, reduced side-effects of CPT-11 (irinotecan) in mice. Br J Cancer 86, 983-988.

122. Germain E, Lavandier F, Chajès V, et al. (1999) Dietary $n-3$ polyunsaturated fatty acids and oxidants increase rat mammary tumor sensitivity to epirubicin without change in cardiac toxicity. Lipids 34, Suppl. 1, S203.

123. Huan M, Cui H, Teng Z, et al. (2012) In vivo anti-tumor activity of a new doxorubicin conjugate via $\alpha$-linolenic acid. Biosci Biotechnol Biochem 76, 1577-1579.

124. Wynter MP, Russell ST \& Tisdale MJ (2004) Effect of $n$-3 fatty acids on the antitumour effects of cytotoxic drugs. In Vivo 18, 543-547.

125. Hardman WE, Moyer MP \& Cameron IL (2000) Dietary fish oil sensitizes A549 lung xenografts to doxorubicin chemotherapy. Cancer Lett 151, 145-151.

126. Cha MC, Meckling KA \& Stewart C (2002) Dietary docosahexaenoic acid levels influence the outcome of arabinosylcytosine chemotherapy in L1210 leukemic mice. Nutr Cancer 44, 176-181.

127. Xue H, Le Roy S, Sawyer MB, et al. (2009) Single and combined supplementation of glutamine and $n$-3 polyunsaturated fatty acids on host tolerance and tumour response to 7-ethyl10-[4-(1-piperidino)-1-piperidino]carbonyloxy-camptothecin (CPT-11)/5-fluorouracil chemotherapy in rats bearing Ward colon tumour. Br J Nutr 102, 434-442.

128. Yam D, Peled A \& Shinitzky M (2001) Suppression of tumor growth and metastasis by dietary fish oil combined with vitamins E and C and cisplatin. Cancer Chemother Pharmacol 47, 34-40.

129. Kimura Y, Takaku T, Nakajima S, et al. (2001) Effects of carp and tuna oils on 5-fluorouracil-induced antitumor activity and side effects in sarcoma 180-bearing mice. Lipids 36, 353-359.

130. Barnés CM, Prox D, Christison-Lagay EA, et al. (2012) Inhibition of neuroblastoma cell proliferation with omega-3 fatty acids and treatment of a murine model of human neuroblastoma using a diet enriched with omega-3 fatty acids in combination with sunitinib. Pediatr Res 71, 168-178.

131. Bradley MO, Webb NL, Anthony FH, et al. (2001) Tumor targeting by covalent conjugation of a natural fatty acid to paclitaxel. Clin Cancer Res 7, 3229-3238.

132. Wang Y, Li L, Jiang W, et al. (2005) Synthesis and evaluation of a DHA and 10-hydroxycamptothecin conjugate. Bioorg Med Chem 13, 5592-5599.

133. Colas S, Mahéo K, Denis F, et al. (2006) Sensitization by dietary docosahexaenoic acid of rat mammary carcinoma to anthracycline: a role for tumor vascularization. Clin Cancer Res 12, 5879-5886.

134. Manni A, Xu H, Washington S, et al. (2010) The impact of fish oil on the chemopreventive efficacy of tamoxifen against development of $N$-methyl- $N$-nitrosourea-induced rat mammary carcinogenesis. Cancer Prev Res (Phila) 3, 322-330.

135. Colas S, Paon L, Denis F, et al. (2004) Enhanced radiosensitivity of rat autochthonous mammary tumors by dietary docosahexaenoic acid. Int J Cancer 109, 449-454.

136. Hajjaji N, Besson P \& Bougnoux P (2012) Tumor and non-tumor tissues differential oxidative stress response to supplemental DHA and chemotherapy in rats. Cancer Chemother Pharmacol 70, 17-23.

137. Manni A, Richie JP Jr, Xu H, et al. (2011) Effects of fish oil and Tamoxifen on preneoplastic lesion development and biomarkers of oxidative stress in the early stages of $\mathrm{N}$-methyl- $\mathrm{N}$ nitrosourea-induced rat mammary carcinogenesis. Int $J$ Oncol 39, 1153-1164.

138. United States Environmental Proctection Agency (1988) Recommendations for and documentation of biological values for use in risk assessment (EPA/600/6-87/008). http:// www.tera.org/Tools/ratmousevalues.pdf (accessed December 2014).

139. Hajjaji N, Couet C, Besson P, et al. (2012) DHA effect on chemotherapy-induced body weight loss: an exploratory study in a rodent model of mammary tumors. Nutr Cancer 64, 1000-1007.

140. Fasano E, Serini S, Cittadini A, et al. (2015) Long-chain n-3 PUFA against breast and prostate cancer: which are the appropriate doses for intervention studies in animals and humans? Crit Rev Food Sci Nutr (epublication ahead of print version 21 April 2015).

141. Serini S, Innocenti I, Piccioni E, et al. (2010) The effects of omega-3 polyunsaturated fatty acids against cancer. In Vitamins in the Prevention of Human Diseases, pp. 679-696 [W Hermann and R Obei, editors]. Berlin: De Gruyter.

142. Calviello G \& Serini S (2010) Introduction: omega-3 PUFAs, why are we speaking of them? In Dietary Omega-3 
Polyunsaturated Fatty Acids and Cancer, pp. ix-xxi [G Calviello and S Serini, editors]. Dordrecht: Springer.

143. van der Meij BS, Langius JA, Smit EF, et al. (2010) Oral nutritional supplements containing $(n-3)$ polyunsaturated fatty acids affect the nutritional status of patients with stage III non-small cell lung cancer during multimodality treatment. J Nutr 140, 1774-1780.

144. Finocchiaro C, Segre O, Fadda M, et al. (2012) Effect of $n-3$ fatty acids on patients with advanced lung cancer: a doubleblind, placebo-controlled study. Br J Nutr 108, 327-333.

145. Murphy RA, Mourtzakis M, Chu QS, et al. (2011) Nutritional intervention with fish oil provides a benefit over standard of care for weight and skeletal muscle mass in patients with nonsmall cell lung cancer receiving chemotherapy. Cancer 117, 1775-1782.

146. Murphy RA, Mourtzakis M, Chu QS, et al. (2011) Supplementation with fish oil increases first-line chemotherapy efficacy in patients with advanced non-small cell lung cancer. Cancer 117, 3774-3780.

147. Trabal J, Leyes P, Forga M, et al. (2010) Potential usefulness of an EPA-enriched nutritional supplement on chemotherapy tolerability in cancer patients without overt malnutrition. Nutr Hosp 25, 736-740.

148. Bonatto SJ, Oliveira HH, Nunes EA, et al. (2012) Fish oil supplementation improves neutrophil function during cancer chemotherapy. Lipids 47, 383-389.

149. Mocellin MC, Pastore e Silva Jde A, Camargo Cde Q, et al. (2013) Fish oil decreases C-reactive protein/albumin ratio improving nutritional prognosis and plasma fatty acid profile in colorectal cancer patients. Lipids 48, 879-888.

150. Szkaradkiewicz A, Marciniak R, Chudzicka-Strugała I, et al. (2009) Proinflammatory cytokines and IL-10 in inflammatory bowel disease and colorectal cancer patients. Arch Immunol Ther Exp (Warsz) 57, 291-294.

151. Chung YC \& Chang YF (2003) Serum C-reactive protein correlates with survival in colorectal cancer patients but is not an independent prognostic indicator. Eur J Gastroenterol Hepatol 15, 369-373.

152. Sunpaweravong S, Puttawibul P, Ruangsin S, et al. (2014) Randomized study of antiinflammatory and immunemodulatory effects of enteral immunonutrition during concurrent chemoradiotherapy for esophageal cancer. Nutr Cancer 66, 1-5.

153. Bougnoux P, Hajjaji N, Ferrasson MN, et al. (2009) Improving outcome of chemotherapy of metastatic breast cancer by docosahexaenoic acid: a phase II trial. Br J Cancer 101, 1978-1985.

154. Ghoreishi Z, Esfahani A, Djazayeri A, et al. (2012) Omega-3 fatty acids are protective against paclitaxel-induced peripheral neuropathy: a randomized double-blind placebo controlled trial. BMC Cancer 12, 355.

155. Chaudhry V, Rowinsky EK, Sartorius SE, et al. (1994) Peripheral neuropathy from taxol and cisplatin combination chemotherapy: clinical and electrophysiological studies. Ann Neurol 35, 304-311.

156. Hutchins-Wiese HL, Picho K, Watkins BA, et al. (2014) High-dose eicosapentaenoic acid and docosahexaenoic acid supplementation reduces bone resorption in postmenopausal breast cancer survivors on aromatase inhibitors: a pilot study. Nutr Cancer 66, 68-76.
157. Santen RJ (2011) Clinical review: effect of endocrine therapies on bone in breast cancer patients. J Clin Endocrinol Metab 96, 308-319.

158. Arshad A, Chung WY, Steward W, et al. (2013) Reduction in circulating pro-angiogenic and pro-inflammatory factors is related to improved outcomes in patients with advanced pancreatic cancer treated with gemcitabine and intravenous omega-3 fish oil. HPB (Oxford) 15, 428-432.

159. Rahbari NN, Reissfelder C, Mühlbayer M, et al. (2011) Correlation of circulating angiogenic factors with circulating tumor cells and disease recurrence in patients undergoing curative resection for colorectal liver metastases. Ann Surg Oncol 18, 2182-2191.

160. Fietkau R, Lewitzki V, Kuhnt T, et al. (2013) A diseasespecific enteral nutrition formula improves nutritional status and functional performance in patients with head and neck and esophageal cancer undergoing chemoradiotherapy: results of a randomized, controlled, multicenter trial. Cancer 119, 3343-3353.

161. Bükki J, Stanga Z, Tellez FB, et al. (2013) Omega-3 poly-unsaturated fatty acids for the prevention of severe neutropenic enterocolitis in patients with acute myeloid leukemia. Nutr Cancer 65, 834-842.

162. Wolff AC, Donehower RC, Carducci MK, et al. (2003) Phase I study of docosahexaenoic acid-paclitaxel: a taxane-fatty acid conjugate with a unique pharmacology and toxicity profile. Clin Cancer Res 9, 3589-3597.

163. Fracasso PM, Picus J, Wildi JD, et al. (2009) Phase 1 and pharmacokinetic study of weekly docosahexaenoic acidpaclitaxel, Taxoprexin, in resistant solid tumor malignancies. Cancer Chemother Pharmacol 63, 451-458.

164. Payne M, Ellis P, Dunlop D, et al. (2006) DHA-paclitaxel (Taxoprexin) as first-line treatment in patients with stage IIIB or IV non-small cell lung cancer: report of a phase II openlabel multicenter trial. J Thorac Oncol 1, 984-990.

165. Jones RJ, Hawkins RE, Eatock MM, et al. (2008) A phase II open-label study of DHA-paclitaxel (Taxoprexin) by 2-h intravenous infusion in previously untreated patients with locally advanced or metastatic gastric or oesophageal adenocarcinoma. Cancer Chemother Pharmacol 61, 435-441.

166. Homsi J, Bedikian AY, Kim KB, et al. (2009) Phase 2 open-label study of weekly docosahexaenoic acid-paclitaxel in cutaneous and mucosal metastatic melanoma patients. Melanoma Res 19, 238-242.

167. Bedikian AY, DeConti RC, Conry R, et al. (2011) Phase 3 study of docosahexaenoic acid-paclitaxel versus dacarbazine in patients with metastatic malignant melanoma. Ann Oncol 22, 787-793.

168. Homsi J, Bedikian AY, Papadopoulos NE, et al. (2010) Phase 2 open-label study of weekly docosahexaenoic acidpaclitaxel in patients with metastatic uveal melanoma. Melanoma Res 20, 507-510.

169. Thornton E, Howard SA, Jagannathan J, et al. (2012) Imaging features of bowel toxicities in the setting of molecular targeted therapies in cancer patients. Br J Radiol 85 , 1420-1426.

170. Ederhy S, Izzedine H, Massard C, et al. (2011) Cardiac side effects of molecular targeted therapies: towards a better dialogue between oncologists and cardiologists. Crit Rev Oncol Hematol 80, 369-379. 